Authors: S Norfolk and M Cosijn

\title{
TOWARDS THE LEGAL RECOGNITION AND GOVERNANCE OF FOREST ECOSYSTEM SERVICES IN MOZAMBIQUE
}

\section{ISSN 1727-3781}

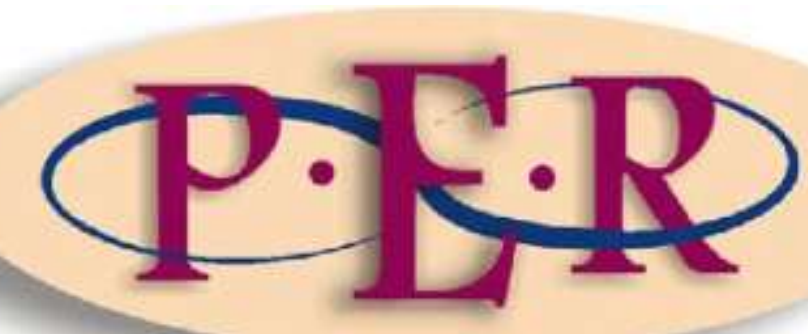

2013 VOLUME 16 No 2

http://dx.doi.org/10.4314/pelj.v16i2.5 


\section{TOWARDS THE LEGAL RECOGNITION AND GOVERNANCE OF FOREST ECOSYSTEM SERVICES IN MOZAMBIQUE}

S Norfolk* and M Cosijn**

\section{Introduction}

\section{Box 1 -Definition of forest and woodlands}

The UN Framework Convention on Climate Change defined forests and woodlands as having between $10 \%$ to $40 \%$ canopy closure.

FAO (2000) defines forest ecosystems as areas that are dominated by trees (perennial woody plants taller than $5 \mathrm{~m}$ at maturity), where tree cover exceeds $10 \%$ and the area is larger than $0.5 \mathrm{ha}$ and includes areas for production, protection, multiple use or conservation, and stands on agricultural land. This was the basic definition used by the Millenium Ecosystem Assessment (2005)

In the Mozambican Law on Forestry and Wildlife (Law $10 / 99$ of $7^{\text {th }}$ June) forests are defined as "vegetation cover capable of supplying wood or vegetative products, sheltering fauna and which exercise a direct or indirect effect on soils, climate or hydrology regimes".
The Millennium Ecosystem Assessment (Millenium Ecosystem Assessment, 2005 carried out between 2001 and 2005) defined 'ecosystem services' as 'the benefits people obtain from ecosystems.' It identified four categories of ecosystem services, including provisioning, regulating, cultural, and supporting.

Many of these services are directly related to forests (see Box 1 for various definitions of "Forest"), which are critically important for terrestrial biodiversity maintenance; air quality regulation; the regulation of the global carbon cycles; soil regeneration and protection; and the regulation of freshwater and groundwater cycles and quality. Forests, including woodlands (see the box on definitions), especially in developing countries, play a vital role in human well-being through the provision of food, fuel, medicinal plants, material for shelter, income, mitigating and reducing disasters, and the less tangible aspects of cultural, aesthetic and spiritual well-being.

Simon Norfolk, LLB (University College, London). Director of Terra Firma, a Mozambican consultancy company specialising in the fields of land, environmental, forestry and natural resource policies. Email: Simon.Norfolk@gmail.com.

** Michaela Cosijn, BSc in Environmental and Geographical Sciences (University of Cape Town), Honours in nvironmental and Geographical Sciences (University of Cape Town), MSc in Integrated Environmental Sciences ( Southampton University, UK). Environmental Consultant. Email: Michaela.Cosijn@gmail.com.

1 UNEP Millennium Ecosystem Assessment http://millenniumassessment.org/en/index.html 
The Millennium Ecosystem Assessment Report (the MA) ${ }^{2}$ identified that the development of improved governance systems to control and reduce the degradation of all ecosystems services including forests was of key importance. This governance needs to be adaptive, including ensuring that the following components are integrated: ${ }^{3}$

(i) it must focus on policy and institutional intersections and cooperation at various levels;

(ii) it must be flexible to rapid change, and ensure that policy and legal changes are incremental and adaptive with continuous learning;

(iii) it must create mechanisms for sustainable forest management (SFM) and livelihoods by securing the rights to forestry goods and services; and

(iv) it must create regulatory mechanisms which control activities, develop compensation mechanisms for those, and develop multi-scalar knowledge and stakeholder sharing, social networks and learning mechanisms.

However, governance systems are rarely adaptive. Instead they tend to be "stuck" in what is called the local minima (or lowest functioning system). These are in many cases dependent on the history of countries, how the governance systems have evolved, and whether or not these systems are open and transparent and able to adapt quickly, but along a gradient of transition and evolution rather than in a "knee-jerk" response that does not build on the best of existing structures. ${ }^{4}$

Within the context of Mozambique, this paper examines the state of forest ecosystem services, the dependency of the population on these systems for their well-being, if an adaptive governance regime is being created which will ensure the resilience of the forest ecosystem services including the legal framework, the institutions operating within this framework, the tools available and their functioning, and how cooperative governance is operating.

WRI Millenium Ecosystem Assessment Synthesis Report.

Katere, Minag and Vanhanen (eds) Making Sub-Saharan African Forests Work.

Katere, Minag and Vanhanen (eds) Making Sub-Saharan African Forests Work. 


\subsection{State of the forest ecosystem services}

Marzolli ${ }^{5}$ estimates forest cover in Mozambique to be 40.1 million hectares. This includes dense and open forests, mangroves, and open forests in flood plains (see table 1). The dominant forest biome of miombo covers almost two thirds of Mozambique, from the Limpopo River to the northern border, including large portions of Niassa, Nampula, Cabo Delgado, Manica, Zambézia, Tete and Sofala provinces. Smaller patches are found in Gaza and Inhambane provinces further to the south. The second largest forest biome is mopane woodland, which is found between the Limpopo and Save Rivers and on the highland areas of the Zambezi River Basin, in areas where rainfall varies between $450 \mathrm{~mm}$ and $710 \mathrm{~mm}$. Along the coast, there are smaller patches of coastal forest, and montane forests occur in the mountainous areas in the north west of the country 6.27 million hectares (67\%) is classified as productive (i.e. high value timber) favourable for timber production and annual harvesting licences of less than $500 \mathrm{~m}^{3}$ and in which forest concessions and annual harvesting licences are mainly allocated. In addition, 13 million hectares $(22 \%)$ of the forest area is legally protected in national parks and other reserves.

Table 1 - Total area (1000ha) of forest and other wood formations

\begin{tabular}{|l|l|l|l|l|l|}
\hline & Total & $\begin{array}{l}\text { Dense } \\
\text { forests }\end{array}$ & $\begin{array}{l}\text { Open } \\
\text { forests }\end{array}$ & Mangroves & $\begin{array}{l}\text { Open forests in } \\
\text { flooded areas }\end{array}$ \\
\hline Forests & $40,068.0$ & $22,518.7$ & $16,390.0$ & 357.0 & 802.3 \\
\hline & Total & Mangroves & Shrubs & $\begin{array}{l}\text { Forests with itinerant } \\
\text { agriculture }\end{array}$ \\
\hline $\begin{array}{l}\text { Other } \\
\text { formations }\end{array}$ & $14,712.2$ & $1,093.1$ & $8,051.0$ & $5,568.1$ \\
\hline
\end{tabular}

Source: Marzolli Avaliacao Integrada das Florestas. 
Forest ecosystems provide habitat for a diversity of fauna including 216 mammal spp, 735 bird spp, 167 reptile spp, 79 amphibian spp, and 3,074 insect spp, totalling 4,271 species. $^{7}$ Over $80 \%$ of all mammal spp in Mozambique are found in miombo forest. There are an estimated 1,356 vascular plant spp, of which more than 450 may be endemic. ${ }^{8}$

Forest ecosystems, especially the miombo woodlands, are also critical for water quality, groundwater recharge, and flow retention, as they surround many of the lakes, major rivers, such as the Limpopo, Zambezi, Messalo, and Rovuma Rivers, and the ephemeral small rivers critical for water supplies in the dry season. In total, Mozambique has 104 river basins draining from the highlands in the west to the Indian Ocean, and over 100 lakes, lagoons, marshes, wetlands, dams, and aquifers.

Alien forest plantations have been increasing in the last decade, especially in Niassa and Manica provinces. However, this area is still very small, covering only 15,000 20,000 ha. These plantations are dominated primarily by Pinus spp and Eucalyptus spp. ${ }^{9}$

\subsection{State of human well-being}

Productive and healthy ecosystems are critical in terms of supplying options and alternatives for well-being and economic development. This is particularly the case where people are economically poor and have a high reliance on natural resources, such as the provisioning services of ecosystems (including firewood, building material, water and food for domestic animals) and are vulnerable, which relates to the resilience of an individual or a household to overcome natural or human induced shocks and risks, including loss of income, or changes in the natural resource base through exposure to floods.

MICOA Evaluation of the Interaction between Biodiversity and Poverty.

Nhancale et al Small and Medium Forest Enterprises.

Nhancale et al Small and Medium Forest Enterprises. 
In addition, in developing countries the regulating and buffering services of ecosystems are critical in terms of maintaining and enhancing livelihoods (including biodiversity, soil fertility, flood control, drought mitigation and water regulation).

Since the end of the civil war in 1992 Mozambique has had substantial economic growth. The GDP has varied between $5 \%$ in the first decade to as high as $8.7 \%$ in 2005. However, Mozambique continues to be one of the ten poorest countries in the world, with $59.6 \%$ of the population living below USD1.25 per day, and $81.8 \%$ living on less than USD2 per day, based on the 2008 national census. Literacy levels are very low (44.5\% in persons over 15 years of age), infant mortality is high (76.9 per 1000 infant births) and life expectancy low (49 years) and declining with increasing levels of HIV/AIDS. ${ }^{10}$ Over $53 \%$ of the population is undernourished and in certain provinces $56 \%$ of children are malnourished. ${ }^{11}$ Income distribution is highly skewed in favour of urban populations, and geographically to the south around Maputo. The majority of the gains in income are going to the top $20 \%$ of the population. ${ }^{12}$

A report written for the UNEP by IISD ${ }^{13}$ identified the following aspects of human well-being as under increasingly severe stress: the ability to be nourished, the ability to have access to clean water, the ability to earn a livelihood, and the ability to access energy, and identified the population as being particularly vulnerable to natural disasters. Forest ecosystems play a vital role in all of these components of well-being in Mozambique, with over $63.9 \%$ of the population living in rural areas, and urban populations relying heavily on the forest for the provision of energy, building materials and food.

Over $80 \%$ of Mozambicans rely on subsistence farming for nourishment, even in urban areas, although some cash crops such as sugarcane, tobacco, cashew nuts, and cotton are also grown by small farmers. Forest fruits and plants are critical in

\footnotetext{
UN World Statistics Pocketbook.

Wong, Roy and Duraiappah Connecting Poverty and Ecosystem Services.

Hanlon Poverty Decreasing in Mozambique?

Wong, Roy and Duraiappah Connecting Poverty and Ecosystem Services.
} 
terms of the provision of food during the year, especially during stress periods and for medicinal purposes.

In terms of access to clean water, the majority of the rural population relies on surface waters such as rivers, streams, and lakes. Only $35.7 \%$ of the population has access to safe and clean water. On average, women walk 1 to $2 \mathrm{~km}$ to obtain water, with some women walking over $20 \mathrm{~km}$ per day to obtain water, especially in the dry season. The ability of forest ecosystems to improve water quality and quantity through the filtration and slow-release functions is not well understood in Mozambique. All provinces except Niassa are exposed to water stresses. These stresses will only increase as the effects of climate change are felt. In the National Institute for the Management of Natural Disasters Report on climate change disaster risk management, ${ }^{14}$ it is predicted that by 2025 water scarcity will be a major source of conflict through-out the country, and that the conflict will be exacerbated by the fact that the major rivers are all trans-boundary. Their upper catchments management and conservation are beyond the control of the Mozambican government. Neighbouring countries are also likely to experience even more severe water crises during this period.

The ability to earn a living for the majority of the population is based on the extraction and use of natural resources, and includes crops, fishing, and the use and sale of forest products. Of the 118 species of trees which have been identified in Mozambique, 31 native species have commercial value but only 10 are exploited commercially for national and international markets. The forestry sector provides 200,000 formal jobs. ${ }^{15}$ The formal sector contributed between 7 and $11 \%$ to total manufacturing income, and $1.8 \%$ to GDP between 2001 and $2002^{16}$ and exports amounted to USD30 million ( $2 \%$ of total exports). ${ }^{17}$ This value grossly underestimates the contribution of the informal sector to the generation of incomes. The informal sector employs at least 600,000 additional people through the production,

\footnotetext{
Van Logchem and Brito (eds) Synthesis Report.

Nhancale et al Small and Medium Forest Enterprises.

Ministerio da Industria e Comercio Estrategia para o Desenvolvimento.

Nhancale et al Small and Medium Forest Enterprises.
} 
transport and retailing of timber, firewood and charcoal, and other forestry products such as honey, twine, alcoholic beverages, and building materials. ${ }^{18}$

Access to energy to keep warm and cook is a necessary contributor to human wellbeing. Due to the low levels of electrification in Mozambique (only $7 \%$ of the population have access to electricity) and its relative expense, charcoal and firewood accounts for $90.5 \%$ of rural energy use and $85 \%$ across the whole country, figures which indicate a high usage level in urban areas. It is estimated that $17 \mathrm{~m}^{3}$ of biomass are removed from the system each year. In $200522,029,000 \mathrm{~m}^{3}$ of wood was used for charcoal alone. ${ }^{19}$

Finally, security against extreme events and drought in Mozambique is becoming increasingly precarious. Catchments are being altered rapidly due to deforestation, resulting in an increased frequency of flooding. Similarly, deforestation is resulting in desertification and drought in certain areas, especially in the south. Recurring extreme events are having a detrimental effect on the ability to access water and earn a livelihood. Household security is therefore declining and vulnerability increasing. These extreme events will be exacerbated by climate change with the concomitant higher temperatures and the increasing variability and
Box 2- summary of the Main Divers of Forest Ecosystem Change

In summary the main divers of change include:

- Subsistence agriculture, which is a key driver of deforestation in Mozambique. An average Mozambican household cultivates 1 to 5 ha of land annually for subsistence crops such as cassava, maize, sorghum, millet and groundnuts. Due to poor agricultural practices, new areas are cleared every 2 to 5 years, increasing deforestation. In most cases, fire is used as a mechanism of clearance. It is estimated that $39.6 \%$ of land is affected by fire annually, with $73 \%$ of the northwest being burned annually (INGC, 2009).

- Firewood and charcoal consumption, which is also a huge driver of change. Sitoe (2007) indicates an average consumption of wood-fuel of $2 \mathrm{~m}^{3} /$ person/year. This is greater than the annual regeneration rates of miombo woodlands per hectare. MICOA (2008) estimates that along key transport corridors, around urban settlements and most of the coastal zone, over $80 \%$ of the forest biodiversity could be lost by 2025 if the status quo is maintained, (i.e. population growth to 28 million people, and largely rural with limited economic development and livelihoods alternatives, and a large reliance on subsistence agriculture and forest products for energy).

- The clearance of land for commercial agriculture and forestry, the mining industry and urbanisation. Figures were not available, but these are increasingly substantial contributors to deforestation in Mozambique.

\footnotetext{
18 Nhantumbo and Izindine Preparing for REDD. 19 DNTF Relatorio Annual do Sector de Terras e Florestas, MICOA Evaluation of the Interaction
between Biodiversity and Poverty.
} 
intensity of rainfall. ${ }^{20}$

\subsection{Drivers of change}

The forest landscapes and ecosystem services in Mozambique are rapidly changing. Between 1990 and 2002 the annual rates of deforestation were $0.58 \%$, and within Maputo Province the rate was $1.67 \% .{ }^{21}$ Box 2 contains a summary of the state of the ecosystem services and the human-induced drivers of change, including subsistence agriculture, commercial agriculture and forestry, urbanisation, mining, and charcoal and firewood extraction.

With $43.5 \%$ of the population below the age of 15 and needing to fulfil their basic needs, and increasing development pressures from extractive industries and commercial agriculture, the pressures on forests will only increase. It is clear that the rapid rate of deforestation occurring in Mozambique will have a major impact on biodiversity and cause a decline in water quality and the regulation of quantities, causing flooding but also longer dry periods. It will also reduce the resilience of ecosystems and people to extreme events related to the climate variability predicted with climate change. The degradation of forest ecosystems is already having a direct impact on the vulnerability of households, resulting in increased poverty, and will continue to do so in future (see Appendix 1).

Governance is a driver of both the supply of ecosystem services and of how they are distributed between different stakeholders, especially the poor. Changes in governance structures and institutions at local or other levels can seriously affect the supply of ecosystem services in quantity, quality, and access. The rest of this paper will examine how governance systems in Mozambique are working to reduce the degradation and decline, as well as allowing access to the use of these resources.

Van Logchem and Brito (eds) Synthesis Report.

DNTF Relatorio Annual do Sector de Terras e Florestas. 


\section{Legal recognition of forestry ecosystem services: law and practices}

\subsection{Constitutional principles regarding the environment and natural resources}

The 1990 Constitution, amended in the lead-up to the peace agreement of 1992, has been referred to by some commentators as the 'environmental constitution. ${ }^{22}$ It introduced a number of clauses which consecrated the rights of citizens to living in a balanced environment and imposed a duty on the state to maintain an 'ecological equilibrium' in the country. It mandates the promotion of 'balanced economic and social development of the country' and establishes the right of citizens to live in a balanced environment. This right is mirrored by a corresponding duty imposed on all citizens to defend and conserve the environment. ${ }^{23}$

The Constitution further requires the state and local authorities to "adopt policies that protect the environment and ensure the responsible use of natural resources". ${ }^{24}$ The state must adopt policies that prevent and control pollution and erosion, integrate environmental objectives in sector policies, and promote the integration of environmental values in its education policy and programmes. It is also required to guarantee the sustainable use of natural resources and ecological stability for future generations, and to promote land use planning in order to ensure that activities take place in the correct locations, and that such activities contribute to balanced socioeconomic development.

With respect to natural resources, the Mozambican Constitution entrenches the concept that the state is the paramount owner of the natural resources occurring within its national territory. ${ }^{25}$ Land ownership, for example, is vested in the state and

See also Norfolk and Cosijn "Development and the balancing of interests in Mozambique" 302-303.

Articles 45(f) and 90(1) Constitution.

Article $90(2)$ Constitution.

Article 98 Constitution. 
no land may be sold, mortgaged, or otherwise encumbered or alienated. ${ }^{26}$ This has a strong impact on natural resource management. Forest resources are similarly treated in the subsidiary legislation. The Constitution requires that the state develop and determine the conditions under which citizens and others may access natural resources for their use and enjoyment. Certain rights of use and enjoyment may then be granted to individuals and collective persons by the government, with priority given to direct users and producers. ${ }^{27}$

\subsection{Overview of the legal framework}

Mozambique possesses a reasonably comprehensive legal framework for land and forest resources, and a well-developed raft of environmental laws designed to protect and safeguard ecosystem services. The environmental laws, in particular, are specifically designed to balance competing interests and ensure that decision-making in respect to development is based on accurate assessments of the potential impacts, and on thorough consultation with potentially affected parties. ${ }^{28}$

The National Environmental Policy was approved by Resolution 5/95 of the 3rd August, 1995. Following the approval of the policy, the Environmental Framework $L_{a} w^{29}$ was approved with the objective of defining the legal basis for the proper use and management of the environment. The Environmental Framework Act 20 of 1997 provides for the participation of local communities, among others, in the development of policy and laws for NRM, the management of protected areas, and policing environmental norms and regulations. ${ }^{30}$

Article 109 Constitution.

Article 101 Constitution.

See in this regard Norfolk and Cosijn "Development and the balancing of interests in Mozambique" 295-340.

Law 20/97 of 1 October 1997.

30 See also See also Norfolk and Cosijn "Development and the balancing of interests in Mozambique" 304-306. 
The Land $\operatorname{Law}^{31}$ and related Regulations ${ }^{32}$ are generally viewed as being an appropriate response to the challenges of the current land tenure relationships in Mozambique. Strong statutory protection is provided to the land rights of users, both for the rights awarded for investment purposes and the rights acquired by existing occupiers of land. In general, the land legislation also represents an attempt to address potential conflicts between different user groups, with the state retaining ownership and, therefore, ultimate responsibility (and power) with respect to safeguarding ecosystem services related to land resources.

Forest resources in Mozambique are governed by two pieces of legislation: the Law of Forestry and Wildlife ${ }^{33}$ and its respective Regulations. ${ }^{34}$ The principles enshrined within these laws provide a sound basis for the protection of ecosystem services provided by forest resources. Article 3 contains the following principles:

- of equilibrium: the policies of social and economic development and the preservation and conservation of biodiversity must involve local communities, the private sector and civil society in general, with the object of advancing a sustainable development in the present and for future generations;

- of harmony between local communities and local organs of the State: the promotion of conservation, management and utilisation of forestry and wildlife resources without prejudice to customary practices and in conformity with the principles of conservation and of the sustainable utilisation of forest and wildlife resources, within the framework of decentralisation;

- of private sector participation: involvement of the private sector in the management, conservation and exploitation of forest and wildlife resources, with a view to adding value and imparting greater development for local communities; ${ }^{35}$

Law 19/97 of 1 October 1997.

Decree 66/98 of $8^{t}$ December 1998 and Ministerial Diploma 29-A/2000 of 17 March 2000.

Law 10/99 of 7 June 1999.

Approved by Decree 12/2002 of 6 June 2002.

These principles do, however, appear to reveal a distinction between what the government considers as appropriate roles for the various sectors of civil society: whilst communities are to participate in the 'preservation', 'conservation', 'management' and 'utilisation' of resources, it is the private sector that may involve itself in the 'exploitation' of those resources. 
Taken together, therefore, the laws that set the rules for land and forest use and that seek to establish environmental safeguards and procedures appear to offer a sound basis for the recognition of ecosystem services provided by forest resources. Applied together and underpinned by the tools provided by the territorial planning legislation, these laws could go some way towards ensuring that the services from forest ecosystems form part of the decision-making process in regard to forest use. Unfortunately there are a number of problems. Firstly, the drafting of some of the laws did not fulfil the promise of the principles on which they were based. Secondly, the laws are rarely applied together as part of a framework and the crucial contribution of territorial planning has been completely neglected. And thirdly, a number of institutional failings serve to undermine the legal framework.

The rest of this section examines the legal concepts within these laws with respect to the various categories of ecosystem services, and highlights some of the enduring problems.

\subsection{The approach to provisioning services}

Both the Land Law and the Forestry and Wildlife Law go some way towards recognising the importance of forest provisioning services to the livelihoods of the forest populations, including as key sources of income and sustenance, as detailed in section 1. The Land Law recognises acquired rights to land and the Forestry legislation commits the state to practise the conservation, management, and utilisation of forest and wildlife resources without prejudice to customary practices. Both laws also set out a framework for the commercial exploitation of these resources, but it is in the balancing of these interests with those of conservation and preservation that the real challenge arises.

\subsubsection{The question of ownership}

Whereas the Land Law recognises certain forms of existing occupation and awards a statutory, exclusive right of use and benefit to land, the Forestry and Wildlife Law 
provides a much weaker level of 'ownership' and control over forest resources to the forest-dwelling populations. Thus, the holders of rights to land will have only limited use rights in respect to the forest resources found on that land. Article 9 of the Forestry and Wildlife Law states:

The holders of land tenure, both acquired through occupation or by authorisation, should acquire licences for the exploration of the natural forest and fauna resources found in their areas, unless if it is for their own consumption [emphasis added].

While creating the mechanisms and environment for local communities to participate in the co-management of the resource, the Forestry and Wildlife Law therefore maintains strong de jure state ownership of the resources, granting only subsistence-level user rights to the community. This approach is different from that taken in the Land Law: while the Land Law enables the transfer of real rights to land (which can be subject to transaction), the Forestry Law restricts resource use to non-commercial subsistence levels.

The Forestry and Wildlife Policy ${ }^{36}$ distinguishes three categories of forest, reflecting their relative richness in biodiversity and commercial value, as well as giving an indication of who has access and control over the resources:

- Protected forests, which comprise $16 \%$ of the national territory and are legally under state management. There is increased delegation of management to the private sector, and international conservation organisations have a long history of contributing to the maintenance of these areas.

- Productive forests, which are located mostly in the central and northern parts of the country. These are generally allocated to private operators under long-term concessions or annual licences, but local communities are also eligible to exploit them in this way.

- Multiple-use forests, which are generally subject to competitive uses and users. A substantial part of the rural population lives in these areas.

$36 \quad$ Resolution 8/97 of 1 April 1997. 
As noted, the state owns all resources in the country, but it has the authority to allocate use and improvement rights to different users. Importantly, this includes the right of the state to hold the resources in trust for the people in order to protect the services for society at large (such as biodiversity, water and wetlands maintenance, and other functions). Obviously, this role is critical. In the Mozambique context it is largely mediated through the environmental legislation, and via institutions with an environmental mandate. Sector ministries such as the Department of Land and Forestry remain more concerned with the allocation of use rights and the regulation of the commercial exploitation of resources than with the management and protection of ecological services. ${ }^{37}$

The relative lack of ownership rights for local people in the Forestry and Wildlife legislation is redressed slightly by the statutory payment to them of $20 \%$ of the royalties and taxes received by the state from the private sector forest operators. A Ministerial Diploma ${ }^{38}$ composed of six articles defines the management mechanisms and channelling of this $20 \%$ of the forestry and wildlife revenues.

The government, however, has been slow to deliver these benefits to the forest communities. In order to access the $20 \%$ contribution the community groups need to fulfil a range of conditions (see later). Commentators such as Mourana and Serra $^{39}$ question if in fact this co-management model, in which communities are expected to assist with the management of forest resources in return for payment, is the appropriate model. They suggest that local communities might take more responsibility for the preservation and protection of forest resources if stronger 'ownership' over the resources were devolved to them, as with the Land Law. Instead, the current logic of the law may in fact be driving the involvement of communities in activities that lead to massive deforestation and forest degradation. Johnstone, Cau and Norfolk ${ }^{40}$ suggest that the weak incentives provided by the law mean that community groups and their influential leaders are open to accepting

\footnotetext{
Based on own experience as consultants. Ministerial Diploma 93/2005 of 4 May 2005. Mourana and Serra 20 Passos para Sustentabilidade Florestal. Johnstone, Cau and Norfolk Forestry Legislation.
} 
bribes from illegal operators, an enduring phenomenon widely reported in the sector.

These critiques have led to suggestions that it may be time to harmonise the legal framework on land and other natural resources with respect to the rights of local communities, on the basis that it makes little sense for communities to have rights to land and not to the existing resources on that land.

\subsubsection{Fuel wood, charcoal and timber}

\subsubsection{Exploitation vs protection}

One of the main critiques of the legal framework on forests is that it is overly focused on the use or exploitation of forest resources, rather than on conservation. This critique holds that a major objective of the legislation was to fix the basic rules of licensing of forest exploitation, and that other issues such as forest protection, forest reserves, reforestation, sustainable forestry and other essential components are poorly dealt with. Certainly, the standards dealing with the protection and conservation of forest resources are poorly articulated in the law and the legal protection of ecosystems in general, and biodiversity in particular, is weak.

There are two different regimes for forest exploitation: a long-term concession and an annual simple licence. Of the two, the simple licence system is the most problematic due to its failure to ensure any sustainability in forest resource exploitation. The simple licensing regime is popular with forest operators because, unlike the forest concession system, it brings no obligation with respect to reforestation, no duties towards local communities, it does not require the installation of a processing plant, requires no detailed forest inventory, nor the approval of a plan for the management of the forest resources. There are some vague safeguards in the Regulations: Article 8 of the Regulations, ${ }^{41}$ for example, states that:

41 Decree 12/2002 of 6 June 2002. 
Access to natural resources, even where it is for personal consumption, may not prejudice the norms of protection and conservation, and restrictions may be established taking into account the following:

a) The exploitation of species of flora and fauna whose use or exploitation is prohibited by law;

b) The use of instruments and methods permitted by law;

c) The quotas for the killing/cutting of species of flora and fauna established in terms of this regulation [emphasis added].

For the exploitation of timber, in a context where there is little information on the current state of the resource, the stipulation regarding quotas is meaningless, and in practice the simple licences are awarded for the maximum volume permitted (500 $\mathrm{m}^{3} /$ year), irrespective of whether any current inventory data exists or not.

At a national and international level, policies, aid and trade agreements are important indirect drivers of change, having both positive and negative impacts on ecosystem services. In Mozambique the pressures on forests are growing due to (mainly Chinese) interests in tropical hardwood. Such commercial timber harvesting often occurs at the expense of the poor, as it is they who lose access to a host of important ecosystem services whilst receiving few returns from timber sales. ${ }^{42}$

\subsubsection{Transparency and conflicts of interest}

The regulation of the licensing process, particularly for concessions, is fairly comprehensive, but as with many other areas of administrative adjudication in Mozambique, there is a severe absence of transparency and integrity in the implementation of these laws. A large part of the problem is related to the nonobservance of legislation relating to conflicts of interest. Law 4/90 of 26 September 1990 establishes standards of conduct for senior managers of the state. According to this, Ministers are obliged to relinquish property or shares in any economic activities that fall under the licensing agency over which they are responsible. In addition, Law 7/98 of 15 June 1998 establishes similar standards applicable to the holders of government positions, emphasising the incompatibility of the exercise of certain

$42 \quad$ Based on own observations as consultants. 
government posts with the administration or management of related businesses. As Mourana and Serra ${ }^{43}$ note, there is a huge gap between the law and practice.

The Forestry and Wildlife Law sought to introduce transparency in its adjudication processes through the introduction of representative 'local resource management councils' (COGEPs), which would be responsible for the management of resources in defined areas and which would be composed of several local communities, private sector stakeholders and local state administrative structures.

Given the extent of the powers envisaged for these councils (summarised in Box 3), their establishment would have gone a long way towards introducing a consultative mechanism to address not only the licensing of commercial forest resource exploitation, but also the safeguarding of forest ecosystem services in general. Unfortunately, several years after the passing of the law there is not one example of a local resource management council with formally delegated powers.

\section{Box 3 - Important aspects relating to the COGBEPS}

The Regulations (Decree 12/2002) specify the following important points with respect to these councils:

- they will be comprised of an 'equal' number of representatives from four groups, identified by the regulations to the Forestry and Wildlife Law as being local communities, the private sector, the NGO sector and the State; ${ }^{1}$

- the councils are 'collective persons' and have legal personality, independently of their members; ${ }^{1}$

- within defined territorial or administrative areas the councils have powers to:

pronounce upon requests for forest and wildlife exploitation licences;

take measures to ensure that the sustainable use of resources contributes to rural development especially of local communities;

pronounce upon and propose solutions to conflicts regarding resource use;

facilitate and assist State entities responsible for the enforcement of resource use regulations;

propose measures for the improvement of policy and legislation regarding forest and wildlife resource use;

- unlock actions relating to the control of forest fires;

pronounce upon proposed management plans for resources within their areas of jurisdiction.

- have veto power over 'projects' which are not compatible with rural development and the sustainable use of resources.

43 Mourana and Serra 20 Passos para Sustentabilidade Florestal. 


\subsubsection{Inventories and management plans}

Two key statutory instruments for ensuring that the commercial exploitation of forest resources does not negatively impact on ecosystem services are the requirements for the completion of an inventory and a comprehensive Forest Management Plan (FMP). Both are legal pre-requisites for the approval of a concession. A detailed forest inventory in a concession area is used to establish the sustainable harvesting quotas which are applied for annually at provincial level. Guidelines for the FMPs were developed in 2006 and these address ecological, social, and economic sustainability in a comprehensive manner. An FMP should address issues such as regeneration rates, the protection of sensitive areas in the concession, harvesting, the type of utilisation, employment, etc. There are a number of problems with these inventories and plans, including the following:

- The inventories are of poor quality and the extent of the forest resource is not accurately known within management areas. As a result, there is no obvious and clearly defined relationship between the quantities of forest resources being removed and sustainable levels of harvesting, especially for simplified licences and where there has been poor preparation of the FMPs.

- The management plans need to be produced by authorised consultants. Consultants are expensive and many operators cannot afford the development of a management plan. There are also few consultants accredited by the government to carry out these activities.

- In a context of low enforcement capacity, many of the approved management plans are reduced to a mere formality and have no bearing on the actual activities of the concession operators. Annual harvesting blocks are not strictly demarcated, which means that harvesting can still be selective anywhere in the concession areas. Often there is no planned annual cutting cycle of designated cutting blocks and operators merely look for the best and most profitable species from anywhere in their concession area.

- Many operators have been permitted to initiate their activities without approved management plans. The Annual Report of the National Directorate of Lands and 
Forests for $2007^{44}$ shows that of the 137 existing concessions, only 72 had approved management plans.

- The simplified management plans for simple licence holders (SLHs) are also not being implemented as intended in the regulations. Rather than being a guide to best practice and helping to ensure the long-term management of the forest, they simply list marketable species and the quantity to be exploited.

\subsubsection{Fuel wood and charcoal}

One of the largest negative impacts on the forest resource comes from fuel wood collection and charcoal production. According to the law, any person that makes charcoal for commercial purposes has to be licensed. Only communities and households that extract wood for firewood and making charcoal for household use may do so without a licence. If they sell these resources outside the administrative post where they are resident, they must have either a simple licence or a concession to exploit the timber resources. The law also prohibits the use of hardwoods of certain types to be used for firewood and charcoal, but only if this is for commercial use. Branches and damaged trees of these species can be used, even in commercial exploitation.

In recent years there has been a movement to transfer the charcoal licensing fees from the transporters to the producers, imposing an extra cost per bag upon the producers in some community forest management pilot areas. Unfortunately, the response to this extra cost at producer level has been an increase in the scale of production, rather than an increase in prices. The most vulnerable group, in the least powerful negotiating position, has therefore been punished through the imposition of an extra tax. Huge demand in the urban centres, combined with large price differentials and the inefficiency of poorly paid inspectors, has also led to the appearance of organised groups of charcoal smugglers. 


\subsubsection{Wildlife and food resources}

The provisioning services inherent in the collection of food resources from the forests are legally protected in the Forest and Wildlife legislation, although there are restrictions placed upon these rights. It may be practiced only in areas that are for multiple use, areas that have been zoned as official hunting zones or as being of historical/cultural value, and in productive forest areas. To both practise the hunting and to benefit from the tax exemption, a person must be recognised by a particular community (in accordance with customary norms and practices) as a 'community hunter'. This right is not transmissible and must be verified by a state entity before it comes into existence.

One of the several forms of hunting licences that can be obtained relates to the capture of small game for subsistence purposes by local communities. Here, the law states that the newly formed local committees will be empowered to issue the licences, within the framework of management plans or sustainable norms. Which of these applies depends on the area in which the hunting is to take place. However, the regulations are confusing in this respect and do not refer to the role of the local committees at all, stipulating instead that the licence applicant must be 'recognised' as a local hunter. Licence approval request is done once per year to the governor via the Provincial Forest and Wildlife Services (SPFFB). ${ }^{45}$

\subsubsection{Genetic resources}

There is no legislation designed specifically to regulate the collection, exchange and transfer of plant genetic resources, ${ }^{46}$ although the National Centre of Plant Resources, located in the Institute of Agricultural Research of Mozambique (IIAM), is the main institution promoting the protection of genetic resources through the

\footnotetext{
45 Article 68 Forestry and Wildlife Law Regulations.

46 MEDIMOC is the only company in Mozambique officially allowed to import and export medical products, including domestically collected medicinal plant products. The company was created in 1977 as a government company, it was privatised in 1999, and now operates as a for-profit commercial company.
} 
preservation and promotion of sustainable use. While specific legislation on this topic is being developed, the collection, exchange and transfer of germplasm is apparently being regulated by the guidelines set out in the International Code of Conduct for Plant Germplasm Collecting and Transfer (see below). As no information is available on how this regulation is being implemented, who is responsible for it, and what products it may cover; it is extremely unlikely that any standards are being enforced with any degree of rigour. In terms of forestry resources, IIAM has had limited involvement except during Planet Reviewed Expedition (See Box, section 4.3) and focuses most of its efforts on agricultural research.

According to information from the Ministry of Agriculture (MINAG) a 'Variety Release Committee' has been established, partly to protect national breeders' rights. Further, a National Plant Genetic Resources Committee has been established to ensure the protection of the country's plant genetic resources; and legislation on Plant Breeders Rights has been drafted but has not yet been enacted. There is no legislation dealing with the introduction of genetically modified organisms (GMO), biotechnology and bio-safety, or regulations for risk assessment or management.

\subsection{Protecting benefits obtained from the regulation of ecosystem processes}

The Environmental Law includes provisions for conducting environmental impact assessments (EIAs) for a range of projects that are likely to have significant impacts on the environment. ${ }^{47}$ Proposed developments and activities are categorised according to their perceived potential impact on the environment and this categorisation will then guide the level of rigour with which assessments must be carried out. In addition, several sectoral policies refer to the necessity for EIAs to be carried out for development projects, including tourism, mining, oil and gas, forestry

47 See also Law and Regulation on EIA (Decree No 45/2004); Ministerial Diploma: Addendum to EIA Process Regulation No 45/2004 of 25 September (Diploma 198/2005); Alteration of the Articles 5, 15, 18, 20, 21, 24, 25 and 28 of the Environmental Impact Assessment Regulations of 29 September (Decree 41/2008). 
and wildlife, roads and bridges. ${ }^{48}$ It is the EIA process that ought to act as a major safeguard mechanism for the regulating services provided by forest ecosystems. The role of the EIAs is further examined in section 2.6 below.

Mozambique has an increasing network of protected areas, covering $147,345 \mathrm{~km}^{3}$ $(18 \%)$ of the total country's surface area, including 13 forest reserves. The majority of the forest reserves, however, were established in the 1950s as timber production reserves, with only a few established to protect water catchments for example. ${ }^{49}$ The contribution of forests to watershed maintenance (for the subsequent supply of drinking water, irrigation water, and for power generation) is little understood in Mozambique. The Regulations to the Forestry and Wildlife Law do not refer to water sources in the context of concessions or simple licences and the Land legislation merely states that areas within a certain distance of water sources and river courses are reserved to the state.

People are living within the boundaries of most of the protected areas due to historical circumstances including displacement during the civil war and natural disasters ${ }^{50}$, but as they have limited forms of income and derive little financial benefit from tourism and other activities, they therefore exploit the forest resources within these areas. While government officials are encouraging these populations to resettle, either within the protected areas or outside but in concentrated communities, ostensibly to facilitate the provision of basic services such as water, there is large resistance to such efforts, as the resettlement areas are often far from the ecosystem services on which these communities rely, so that accepting such a move would result in increasing impoverishment.

See also Norfolk and Cosijn "Development and the balancing of interests in Mozambique" 322325.

49 The national network of forest reserves is said to over-represent miombo and coastal forest, while under-representing mangrove and mopane. However, areas of these forest types are conserved in national parks and game reserves, as well as occasionally in locally conserved forest areas, such as the Chirindzene Sacred Forest (Müller, Sitoe and Mabunda Assessment of the Forest Reserve Network.). 
Erosion is a major problem, and there is nothing in the sector legislation that deals with this. A major driver of erosion is deforestation, particularly as a consequence of extra-forest sector activities, such as the conversion of forest land to agriculture. The Forestry and Wildlife Regulations prohibit the use of forest fires as a means to clear land, except in very limited and tightly controlled circumstances, but this prohibition has had little impact on behaviour. While command-and-control is necessary, the limited capacity in terms of number and qualifications of government personnel at all levels entails the need for the development of more innovative approaches.

The Environmental Law contains provisions directly related to the conservation of biodiversity, prohibiting all activities that adversely affect the conservation, reproduction, quality, and quantity of biological resources, especially those threatened with extinction. The law also calls for the special protection of plant species threatened with extinction, or those botanical components, isolated or in groups, requiring protection due to their genetic potential or biological, cultural, or scientific value. These concepts remain undefined in the legislation and no concrete actions have yet been taken to put them into effect. The Forestry and Wildlife Law recognises the role of 'local communities' in the preservation and conservation of biodiversity but does little to flesh this role out, and the key instrument for underpinning local management practices, the local management councils (Conselhos Locais de Gestão Participativa - COGEPs), remains unimplemented.

\subsection{The law and non-material benefits obtained from ecosystems}

The Forestry and Wildlife Law establishes the possibility for communities to 'register' the fact that a particular forest area holds cultural and religious significance for them. Article 13 defines such areas as:

...destined for the protection of religious interests and other sites of historical importance and cultural use, in accordance with the norms and customary practices of the respective local community. ${ }^{51}$ 
Zones of Historical and Cultural Use and Value may be forests situated in rural cemeteries and cult worship areas, forests which contain plants used for traditional medicine, or home to wildlife used by cults. All are considered to be Zones of Historical and Cultural Use and Value, assuming that the exploitation of such species is not prohibited by law. ${ }^{52}$ Within such areas, the law permits the use of resources in terms of customary practices. These uses are distinct from the subsistence level use rights that obtain generally in other areas, and centre mainly on the holding of traditional, cultural and religious ceremonies, as well as local-level prohibitions on entering areas at particular times. The regulations contain provisions that amplify how these areas may be registered. To obtain this status they must be officially declared by the provincial governor and geographically delimited, although the exercise of customary rights within the areas is not prejudiced by the absence of this declaration or the delimitation of the area. ${ }^{53}$

There are two areas of legislative doubt concerning this tenure regime. The first one relates to whether or not the Forest Law regulations satisfy the requirement for a particular decree defining the "terms and conditions" established in article 10(6) of the Forest Law. This article states that the Provincial Governors may so declare areas "on the terms and conditions to be defined by a Council of Ministers' decree". Since the Regulations do not define these terms and conditions, it is doubtful that they apply, and there may still be a legislative gap in this respect. The second area of doubt relates to the absence of a definition in the legislation of "delimitation of geographic area". These grey zones in the legislation may affect the implementation of the Zones of Historical and Cultural Use and Value.

In the 2006 national report under the $\mathrm{CBD}^{54}$ Mozambique stated that it had not carried out an assessment of the knowledge, innovations and practices of farmers and indigenous and local communities in sustaining agricultural biodiversity and agro-ecosystem services for food production and food security.

Chapter II, s II, art 7 Forestry and Wildlife Regulations.

Article 11 Forestry and Wildlife Regulations.

Consortium AGRIFOR Consult 2006 ec.europa.eu. 


\subsection{The role and status of environmental impact assessments}

As discussed in the section on drivers of change, there are numerous activities which are causing large-scale deforestation in Mozambique, including exotic forest plantations, commercial agriculture, the cultivation of biofuels, mining, and to a lesser extent livestock farming, unless pasture is planted. All of these require EIAs under the number of laws and decrees that regulate this process. ${ }^{55}$ Decree 45/2004 introduces the categorisation of projects into various categories: Category $A$, which requires a full EIA (Estudo de Impacto Ambienta); Category B, requiring a Simplified Impact Assessment (Estudo Ambiental Simplificado - EAS); and Category C, which does not require either an EIA or an EAS, although an environmental management plan (EMP) may be requested by MICOA to ensure that any impacts are mitigated and managed. ${ }^{56}$ All of the large-scale projects fall into Category A. In addition, all activities that occur within the protected area network are categorised as category $A$ or $B$, depending on the scale of the proposed project.

For all Category A and B projects, the positive and negative impacts on the biophysical and socio-economic environments need to be evaluated and weighed against each other. All alternatives to the project need to be evaluated, and the resulting report must assess the impacts and propose mitigation measures. An EMP is then developed based on the potential impacts and proposed mitigation measures. The EMP for projects of Category A or B should also contain monitoring and auditing schedules, with scope for review of the EMP to ensure that best practices and learning are continually integrated into the documents. On the face of it, therefore, the framework for balancing development and managing ecosystem services within the EIA process appears sound.

\footnotetext{
55 The Law and Regulation on Environmental Impact Assessment (Decree 45/2004); Ministerial Diploma: Addendum to EIA Process Regulation 45/2004 of 25 September 2004 (Diploma 198/2005); Alteration of the Articles 5, 15, 18, 20, 21, 24, 25 and 28 of the Environmental Impact Assessment Regulations of 29 September (Decree 41/2008).

56 The decree also includes the various stages of the process, including the documentation for submission, government timeframes for evaluation, the public participation process, licensing payment requirements and the registration of environmental consultants.
} 
There are, however, some fundamental limitations in the process, which in many instances cause ecosystem services to be severely degraded and the well-being of local communities to be ignored, including the following: ${ }^{57}$

- Many of the consulting firms accredited to conduct EIAs have limited professional capacity and insufficient experience to understand and correctly identify how the ecological systems are functioning and interacting in the identified project area, the potential impacts and appropriate mitigating measures, especially in large scale developments such as commercial agriculture and the cultivation of biofuels.

- Within the national, regional and international EIA firms which operate in Mozambique there is limited knowledge of the long-term impacts of large-scale projects on the Mozambican environment due to a lack of research and monitoring. Much of the information is extrapolated from the experiences of other countries and never verified locally.

- MICOA has limited financial and human capacity to adequately evaluate EIAs and to undertake the long-term monitoring and auditing of projects to develop a deeper understanding of their impacts. In addition, the decentralisation of powers has shifted the responsibilities for evaluating all category B projects to the provincial offices of MICOA, which have even more severely restricted capacity. Projects which could have a severe impact may be passed with almost no comment, since generically they meet the criteria for categorisation (i.e. any project less than 350 ha for irrigated agriculture is regarded at Category B and they are seen as promoting the development of a particular district); this despite the fact that they may have severe impacts offsite (e.g. in terms of forest clearance and water quality and quantity downstream).

- There is very limited evaluation of alternatives, as the proponent is often reluctant to discuss these and there is lack of the professional experience that would make it possible to propose these.

- The majority of EIAs occur within a planning vacuum and are assessed individually and out of context. Cumulative impacts are rarely considered. When

57 Based on our experiences as consultants in the field. See also Norfolk and Cosijn "Development and the balancing of interests in Mozambique" 322-325. 
they are, the evaluation is very poor. Rarely are downstream impacts considered. Strategic evaluations are presently being undertaken only to determine which areas should be retained as indigenous forest due to their sensitivity, biodiversity, or landscape value. This process is discussed below, but to date has not been effective in guiding development and providing a development framework for forest ecosystem services management. The pervasive subtle message is that miombo woodlands have no real value. The services they provide are not acknowledged, and economic development must take precedence.

- The indirect impacts (such as increased logging through the opening up of the hinterland, in-migration, losses in biodiversity, social pathologies in neighbouring communities, and the breakdown of social structures) are very inadequately addressed. This failure is further exacerbated when communities are resettled out of the project area into surrounding locations.

- There is presently a national drive for sector ministries to approve EIAs and not MICOA, especially in the context of the extraction of oil and gas, and mining. This may have benefits in terms of better technical understanding, but it is likely to be to the detriment of the environmental services, as forests are undervalued in terms of their economic value.

\subsection{The contribution of international conventions ratified by Mozambique}

The Government of Mozambique signed the Convention on Biological Diversity (CBD) in 1992 and ratified it in 1995. Article 6 of the Convention on Biological Diversity calls upon all parties to develop national strategies reflecting the agreements in the Convention. This was completed by Mozambique in 1997. However, the monitoring of progress is difficult because Mozambique has failed to develop any national standards or specifics in relation to the global targets and indicators adopted under the Convention. Reporting on progress in the latest national report is notable for the many references to the "limited technical and financial resources" available for implementation of the activities. It also draws attention to the: 
- Low level of coordination and articulation among different institutions, with overlapping mandates

- Lack of definition of priorities relating to environment and biodiversity during the planning and budgeting of different activities

- Weak implementation of current legislation and policies

- Weak technical and financial capability to enforce the current legislation

- Limited sharing of information related to biodiversity among institutions

- Lack of systematization of the country's biodiversity information.

In addition, there is high reliance on foreign donors to drive the integration of biodiversity and environmental issues into government activities through budgetary support. ${ }^{58}$ This financing is becoming precarious due to increased international financial stresses, but also because of donor reluctance to provide financing if performance proves to be poor.

Mozambique signed the UN Convention to Combat Desertification (UNCCD) on September 28th 1995 and it was ratified on 13 March 1997. It entered into force on 11 June of the same year. A National Action Plan for implementing the UNCCD in Mozambique has, however, not yet been approved. MICOA is the government institution responsible for the coordination of the implementation of the UNCCD and the National Action Plan (once adopted). Other state institutions are involved in the implementation, and MICOA hosts a National Coordinating Body (NCB), the organ in charge of the supervision of implementation of the Convention. The NCB does not have legal existence yet.

Mozambique signed (12 June 1992) and ratified (25 August 1995) the United Nations Framework Convention on Climate Change of 1992. It entered into force on the 23 November 1995. The GoM has submitted its Initial National Communication to the UNFCCC Secretariat in 2006, fulfilling its obligations to the Convention in

$58 \quad 6.3 \%$ of the budget allocated for environmental activities came from foreign donors, and $1.6 \%$ from government, which was a mere $5 \%$ of the budget (Cabral and Francisco Environmental Institutions). 
accordance with Article 12. At the COP 17 in Durban in 2011, the Minister of Energy announced that Mozambique had completed its second national communication. The SADC Protocol on Forestry is a regional policy framework designed to foster cooperation in forestry and to provide a common vision and approach to the management of the region's forest resources. The then SADC Forestry Sector Technical Coordination Unit began work on the protocol in 1998 in collaboration with the World Conservation Union (IUCN). Mozambique was one of three SADC countries (the others were Botswana and Namibia) that did not sign the Protocol in October 2002, and has yet to do so.

\section{$3 \quad$ Key issues in the governance of forest ecosystem services}

\subsection{Integration and institutional coordination}

MICOA is a coordination agency, not an implementation agency, and has the mandate only to coordinate environmental action carried out by other sectoral ministries. $^{59}$ The perception is that MICOA experiences serious difficulties in performing this coordinating role effectively. Part of the problem is that the mechanisms for coordination are not spelled out. Another problem is that MICOA has little political leverage over other sectoral ministries and hence limited scope for influencing sector policies. This limited capacity to influence is exacerbated by the fact that MICOA is poorly endowed in terms of human and financial resources. Examples include the fact that for both the award of simple licences and concession allocations, the MICOA should also have a say in the management plan. This hardly ever takes place. Similarly, an environmental impact assessment is required for forest plantations to establish potential impacts and mitigation measures related to introducing alien species and large areas of monoculture. Again, this seems to take place rarely before the rights to plantations are adjudicated.

59 See also Norfolk and Cosijn "Development and the balancing of interests in Mozambique" 306308 on the work of MICOA, the Ministries and CONDES. 
The National Council for Sustainable Development (CONDES) still does not have a strong presence in environment policy debate or sectoral coordination despite reporting directly to the prime minister's office and consisting of a cross-section of ministers. The council is chaired by MICOA and has the potential to influence policy debate, but so far has not promoted dialogue on important environmental issues during the preparation of sector policies.

\subsection{Cooperative governance and shared decision-making}

The links between governance, democracy, and biodiversity conservation are mutually reinforcing. There are four essential elements of effective democratic governance to consider in biodiversity conservation programmes: participation, decentralisation, information and advocacy, and policy and law. With secure rights and access to land and other resources, local communities can more effectively collaborate in conservation and development programmes. Improvements in public access to information about biodiversity, natural resources, and the environment allow people to more effectively manage and plan for a sustainable future. A suitable enabling environment, in the form of relevant environmental legislation, appropriate reforms, and accountable and transparent mechanisms for policy making is necessary to ensure that resources are managed sustainably over time.

The country's official report under the CBD, from 2009, makes two very interesting observations in respect to governance: ${ }^{60}$

- Firstly, it acknowledges that decisions regarding natural resources utilisation are made mainly without taking into account the results of research, noting that the only time research results and scientific information are used is when there is conflict and controversy

- Secondly, it notes that a lack of investment in research results in uninformed political decision making. This is particularly notable in the land and forest sectors.

60 On cooperative governance in Mozambique, see also See also Norfolk and Cosijn "Development and the balancing of interests in Mozambique" 331-333. 
One of the most important aspects of differentiated access to resources is the question of who decides on resource allocation at what level. This is linked with the state structure, and functions from the national to the local level as determined by the State Administration Ministry on one hand, and the representation of the various government departments from the national to the local level on the other. In Mozambique, representation and functions become ambiguous lower down the structure of governance. In fact at certain points, especially at the local level, there are other structures that emerge, especially traditional authorities and related hierarchies. Positive law is increasingly replaced by or complemented by customary law. We have noted already how the COGEPs, a positive mechanism for ensuring participation and transparency in forest resource allocation and protection, remain an unimplemented instrument of the law.

\subsection{Compliance and enforcement}

The DNTF is responsible for the management and exploitation of forest resources and biodiversity; the management of land and the allocation of rights to use and exploit, supervision and law enforcement, and monitoring infractions and issuing legal penalties. The logging of hardwoods is controlled solely by the DNTF and has increased dramatically in the last 15 years, with the main markets being Asia, and specifically China, with $80 \%$ of all logs being sent to this destination. The three provinces of Sofala, Zambézia and Cabo Delgado account for $70 \%$ of this log cut.

The charcoal chain has been divided into two main areas in terms of governmental institutional arrangements:

- The supply component is under the Ministry of Agriculture through the National Forest Directorate. This directorate focuses on forest industries, concessions, community forestry and wildlife due to the pressure it experiences from the forest industrial sector and private companies, and pays little attention is given to charcoal and wood-fuel supply. 
- The consumer component is the responsibility of the Ministry of Energy and Industry, through the National Energy Directorate. In this directorate attention is centred mainly on electricity supply and fossil fuels due to the pressure of donor communities and energy companies.

Charcoal production falls within an institutional vacuum and interventions in the wood-fuel sector have resulted neither in effective regulation nor in effective control of the sector. ${ }^{61}$ Between 2007 and 2009 the number of licences for charcoal increased by $35 \%$, while it decreased for firewood. The licenced volume of timber for poles increased by 45\% between 2007 and 2009 (Table2 -). In 2009 it was estimated that there were only 1,500 small and medium enterprises ${ }^{62}$ registered to $^{2}$ produce and sell charcoal, but 150,000 unauthorised producers, with between $1 \%$ and $5 \%$ of charcoal production currently registered. ${ }^{63}$ The total market value is estimated at US\$32 to 44 million, considerably higher than for hardwood logging. Similar trends are seen with the other non-timber products such as honey, firewood, and handicraft, although to a lesser extent than with charcoal (see Table 3).

Table2 - Trend of licenses for biomass energy and construction materials, 2007-200964

\begin{tabular}{|l|c|c|c|c|c|}
\hline \multicolumn{1}{|c|}{ Product } & $\begin{array}{c}\text { No } \\
\text { Licenses }\end{array}$ & \multicolumn{4}{c|}{ Licensed volume } \\
\hline & $\mathbf{2 0 0 9}$ & $\mathbf{2 0 0 7}$ & $\mathbf{2 0 0 8}$ & $\mathbf{2 0 0 9}$ & TC (\%) \\
\hline $\begin{array}{l}\text { Charcoal } \\
\text { bags }\end{array}$ & 1,473 & 781,566 & 996,066 & $1,345,007$ & 35 \\
\hline Firewood & 177 & 46,952 & 46,486 & 37,326 & 20 \\
\hline Poles & 168 & 8,849 & 7,734 & 11,188 & 45 \\
\hline Bamboo & 110 & 12,352 & 7,246 & 5,241 & 28 \\
\hline
\end{tabular}

Table 3- Estimates of non-timber forest product (NTFP) small and medium enterprises (SME) ${ }^{65}$

\section{\begin{tabular}{|l|l|l|}
\hline Type of product & Authorised & Unauthorised \\
\hline
\end{tabular}}

61 Van der Plas 1995 www.worldbank.org.

62 These tend to be family- or community-based enterprises. At the lower end of the scale they operate with limited investment. At the higher end they may be organized into associations and some statistical data will be available.

63 Nhancale et al Small and Medium Forest Enterprises.

64 Nhancale et al Small and Medium Forest Enterprises.

65 Nhancale et al Small and Medium Forest Enterprises 10. 


\begin{tabular}{|l|c|c|}
\hline & $\begin{array}{l}\text { (SMEs that are licensed } \\
\text { and/or registered) }\end{array}$ & $\begin{array}{l}\text { (SMEs that are neither registered } \\
\text { nor licensed but are well } \\
\text { organised) }\end{array}$ \\
\hline Honey & 4,000 & 30,000 \\
\hline Handicraft & 1,000 & 6,000 \\
\hline Charcoal & 1,500 & 150,000 \\
\hline Firewood & 350 & 9,000 \\
\hline Total & 6,850 & 195,000 \\
\hline
\end{tabular}

More recently the Ministry of Agriculture and Ministry of Energy have created funds (Energy Fund and Agriculture Development Fund) to promote the sustainable management of forests through NGOs and community involvement. The bureaucracy and procedures to have access to such funds makes it almost impossible for communities and forests to benefit from them.

The main issues in terms of the lack of compliance and the failure of the general management of forest resources are complex and include:

- the low capacity of government to monitor hardwood and other forest product extraction due to poor vocational training of staff, which tends to occur on the job;

- the lack of resources such as vehicles and radios, which limits the ability of staff to monitor the quotas,

- the fact that there are too few government check points, as a result of which permits are being used repeatedly, and

- $\quad$ certain concession holders may be extracting from outside their concession areas. This is very difficult to control and results in over-extraction and the depletion of the hardwoods.

In addition, the strong demand from the external market coincides with the poor governance associated with the extraction of hardwoods in particular. There are many vested interests in the exploitation of hardwoods, which is highly politicised. Corruption is rife ${ }^{66}$ throughout the value chain from the misuse of the simple

66 Environmental Investigation Agency First Class Connections: Log Smuggling, Illegal Logging and Corruption in Mozambique; Mackenzie, Smith and Fairfield, 2005 Insight 416-420. 
licencing system, to transporting the wood, to exporting the logs, which should be processed in-country according to the law. The net result is in many cases a lack of will to effectively control their extraction. Also, unless the market demand for these resources is controlled, these resources will continue to be over-exploited legally and illegally. With the decentralisation process, it is presently the Governors and District Administrators, who are political appointments, who control the activities that occur at a provincial and district level. There is a sense of unease amongst national-level ministries that the technical aspects of forestry (and other sectors such as agriculture and livestock) are being undervalued and neglected, that essentially there is a loss of effective control of such activities, and that the interests of FRELIMO are being put before those of good management.

District and provincial authorities are increasingly under pressure to generate incomes as part of decentralisation, but also due to the decreasing funding available from international donors. ${ }^{67}$ Concern is being expressed in environmental circles that this is resulting in logging licences being issued above sustainable levels, to generate incomes.

In terms of the production of charcoal, unless there are alternative, cheap and effective energy sources this will continue to be one of the main energy sources in Mozambique While the government has a policy to electrify rural areas, the focus is on larger settlements. In remote areas, fires are used for cooking and for light. For cooking purposes, electricity is still an expensive option for most people. Charcoal and firewood are substantially cheaper alternatives. Unless there is a shift in the pattern of pricing, the demand, especially for charcoal, will continue to grow.

67 This is due to the financial crisis in some instances, but also because donors are reducing their budget support. 
Finally, the most complex issue related to the limited control over non-timber products is that their harvesting, processing (where applicable) and sale substantially support the livelihoods of many thousands of people, and until there are viable alternative income sources there is a general reluctance to control their exploitation. The law at this stage is unable to deal with customary use rights when they become commercialised.

\section{The contribution from planning and research}

\subsection{Strategic environmental assessments (SEAS)}

Due to the observed limitations of the EIA process, especially in terms of cumulative and indirect effects and an inability to resolve conflicts between various sector stakeholders, ${ }^{68}$ MICOA initiated a strategic environmental impact assessment process in 2008. The focus has been on the coastal zone, due to the rapidly developing oil and gas industry and mining industry, the fact that $70 \%$ of the Mozambican population lives within $100 \mathrm{~km}$ of the coast, and the high sensitivity of many of the ecosystems. A Strategic Environmental Unit was set up within MICOA, funded by the Dutch Government. The coastal area was split into three areas, north, central and south. Climatologically and physically these areas are different, and in addition they experience different pressures. For example, in the south the pressures relate to urbanisation and tourism development along the coast. In the north, the pressures relate to the oil and gas industry and mining. The aim of the SEA process has been to assess existing environmental and socio-economic conditions. The process is focusing on priority development sectors, such as forestry, fisheries, agriculture (including biofuels), transport and energy in areas under great pressure in terms of the demand for land for development initiatives, and attempts to resolve some of the conflicts and understand the potential trade-offs. The long-term objective will be to provide an overall framework for sustainable development and livelihoods generation, including acceptable changes that can occur. 
However, the process has been fraught with many difficulties. Trying to undertake an SEA process for a coastal area almost $3000 \mathrm{~km}$ long would be regarded as ambitious, even in countries where there is a large body of experienced professionals. In Mozambique, this is the first time SEAs are being implemented, and the lack of experienced professionals has been a huge limitation, both in terms of the consultants who are undertaking the assessment and the capacity in MICOA. At MICOA level, most of the team have no environmental experience and come from a low socio-economic base. There have been many staff changes and SEA training occurred in 2012 only.

To date, the draft documents have been prepared for the three zones and public consultations have been undertaken in the coastal districts. There has been limited analysis on the environmental drivers of change, acceptable trade-offs which could occur, and potential strategies which could be implemented to minimise the degradation. It is unclear how the integrity of the ecosystem systems will be retained and resilience ensured, especially for the forest ecosystem services. It is also unclear how the SEA process will feed into the territorial planning and district planning processes, as no process has yet been defined for this. Doubts are being expressed as to whether this process will also be able to unhinge itself from the political interests in the various sectors, so that environmental resilience will be retained and thresholds not exceeded.

\subsection{Territorial planning and forest inventories}

Territorial planning is a 'new' sector in Mozambique, and has only recently been underpinned by a legislative framework. It is a generally progressive framework, in the sense that it translates into practice most recent international thinking on planning. ${ }^{69}$ Beyond the specific legal framework, it is also strongly rooted in a

69 A principle agreed upon by the consensus of delegations from 92 FAO member states, including Mozambique, during the International Conference on Agrarian Reform and Rural Development (ICARRD), held in Porto Alegre, March 2006, is that "Land and other natural resources are not only economic assets but also cultural, social and historical assets. Therefore, there is a need to address them in an integrated and territorial way through negotiation, dialogue and participatory 
number of related processes that embrace a raft of similar basic principles. This underlines the belief of decision makers in its strength as a tool to support the meeting of objectives that go beyond the territorial planning framework.

It is partly the recent character of the framework, combined with a lack of experience in implementation, that has focussed territorial and land-use planning efforts on completing the narrow legislative obligations of the new framework rather than on responding to the bigger picture of economic development and governance expressed in other policies and laws. In common with other sectors, an ambitious policy is not backed up by the resources for its implementation, and there is a notable lack of the strategic thinking necessary to tackle this in the medium to long term. Also in common with other policy development processes, the subsequent development of the detailed regulations falls short of providing practical guidance. This lacuna is compounded further when bureaucratic actors are left the task of developing guidelines and operating procedures.

The national forest inventories, ${ }^{70}$ all of which provide an assessment of forest resources, including total, commercial and conservation volumes, the location and distribution of productive forest, species composition and forest structures, ought to feed into these territorial planning process but have not done so. Forest inventory maps are a tool to prioritise specific areas with good potential for investment in the exploitation of forest resources, whilst identifying those areas where forest ecosystems ought to be protected. Forest inventories are also essential to prioritise areas that can be considered for the promotion of REDD+ -related funding that promotes the conservation of biomass and biodiversity at the community level.

approaches". The technical document "Participatory and Negotiated Territorial Development (PNTD)", prepared by the FAO on the basis of a number of land use/territorial planning activities, including in Mozambique, provides good insight into recent thinking. www.icarrd.org.

70 Saket Updating of the Exploratory National Forest Inventory, Malleux Avaliação dos Recursos Florestais. 


\subsection{Research institutions and monitoring}

The institutions undertaking research into natural resource management and ecosystem services include private and public academic institutions, government ministries, donors, and NGOs.

At present there are over 29 higher learning institutions in Mozambique,16 public and 13 private, many of which have faculties throughout the country based on educational priorities established by the government, Box 4 - The Planet Reviewed Expedition in Mozambique (2008 and 2009)

as well as the priorities of each university itself. $^{71}$ There are three public universities which offer courses in natural resource management, with the University of Eduardo Mondlane (UEM) being the main public university for these studies. Almost all research is undertaken in the public universities. Much of their research is used by government as a basis for policy-making. UEM coordinated the research for the $1^{\text {st }}$ State of the Environment Report released in May 2011. ${ }^{72}$

There are many limitations, though, which do not favour

Coastal forests have been comparatively well studied in Kenya and Tanzania, but they are very poorly known in Mozambique, even though this country has the largest remaining coastal forest area along the east coast of Africa. Only a very small area is formally protected in the country. An initiative funded and organised through a French NGO, Pro Natura International, and the Paris Natural History Museum, resulted in a reconnaissance and two expedition to Mozambique led by specialists from Kew Gardens, one in November 2008 and the other in November 2009, in conjunction with partners from the Institute of Agrarian Investigation (Instituto de Investigação Agrária de Moçambique (IIAM)), in particular the National Herbarium and Forestry Research Section. The expeditions focused on the coastal forests of Cabo Delgado Province. The main objectives were to determine the distribution, extent, and types of coastal forests in Cabo Delgado Province of north Mozambique; document species composition through field survey and collecting; and provide training in the field and at Kew to Mozambican partners.

A workshop in Maputo (May 2011) presented the findings to the Mozambican authorities. From a collection of over 2000 plants a checklist of 740 plant species was produced, including 36 new species and 68 new records for Mozambique. The remaining extent of forest was calculated using remote sensing and equalled around $400 \mathrm{sq} . \mathrm{km}$. This is significantly less than had previously been suggested. It is estimated that around $80 \%$ of the area has been lost during the past 150 years.

As a result of this initiative, national authorities are attempting to develop a more comprehensive approach to the management and conservation of these areas through the Coastal SEIA process, as well as NGOs such as WWF East African Coastal Forest Eco-region Programme, and other donors. The exact nature of the programme has yet to be seen. 
rigorous scientific research, including a lack of highly trained academic staff (only $14.8 \%$ have a $\mathrm{PhD}$ ); the lack of stable teaching staff, as they are better remunerated in private sector enterprises or externally in the region; the low numbers of students undertaking science studies at tertiary level due to very poor teaching at high-school level; ${ }^{73}$ and the fact that appointments and promotions within public universities are based more on political affiliation than academic competency. $^{74}$

Due to the lack of finances, ${ }^{75}$ research tends to occur in proximity to large cities, where access is relatively easy. A large number of studies have been undertaken in the Maputo Province, but few studies have been undertaken in areas such as Niassa Province due to its remoteness and the lack of academic institutions based in the Province.

In addition, it is difficult to access the research and monitoring undertaken as most of it is not placed online. For example, the first State of the Environment Report for Mozambique, ${ }^{76}$ a critical baseline document in understanding the changes occurring in ecosystems, is not available online. Inter-disciplinary studies, which are key to the management of ecosystems such as forests, are very underdeveloped, although the SIDA programme mentioned above may assist in contributing in this area. Finally, grass-root community knowledge is rarely captured adequately, as most research occurs at a courser scale.

In the Mozambique Science, Technology and Innovation Strategy Report (MOTIS) ${ }^{77}$ there is an acknowledgement that poor research capabilities limit the prospects of using natural resources in a manner that reduces poverty, while limiting resource degradation. In MOTIS the government committed itself to increasing research capacity in the natural sciences and engineering, through promoting human resource

Council of Ministers MOTIS; Pedersen On the Road to the Knowledge Economy.

Bussotti 2010 pambazuka.org.

Over $80 \%$ of the research in 2006 was funded by donors (Council of Ministers, 2006).

MICOA State of the Environment.

Council of Ministers MOTIS. 
development (i.e. improving research standards and increasing the number of graduates in the sciences; increasing the number of students completing secondary school science; developing regional and international cooperation; and developing facilities such as laboratories, especially in high schools. In addition, environmental sustainability is seen as a crosscutting theme in conjunction with gender and HIV. The focus is on research and innovation around governance and institutions, disaster prevention and management, and ethno-botany. The plan is very ambitious and aims to produce almost 7000 academic scientists by $2025,15 \%$ of whom would be qualified in natural resource management. At present there are fewer than 500 of such scientists. ${ }^{78}$

Some progress is being made towards achieving these goals. For example, there are two new initiatives within the UEM that will assist to improve the research capacity. One of them is a programme led by the UN University, in which Germany's Dresden University of Technology (DUT) and UEM will develop a formal relationship to conduct policy-relevant collaborative research, and Master's degrees and PhD programmes focused on natural resources and the ecosystem services they provide, under the name of the Integrated Management of Material Fluxes and of Resources (UNU-FLORES). A key component of the programme will also be training and the development of locally based research solutions. Climate change and developing ways of addressing the impacts will also be a key component with a focus on forests and their role in the macro system.

The second is an initiative taken through SAREC, SIDA's Department for Research and Development Co-operation, which funds twelve programmes, in nine faculties at the University. Future cooperation is focused on improving integrated and interdisciplinary research in the sciences, engineering, arts, veterinary sciences, IT, and history.

In addition there is a government initiative with funding from the European Union, which arose as a result of the release of the first State of the Environment Report in

78 Pedersen On the Road to the Knowledge Economy. 
May 2011, and the identification of gaps in information, as well as the decline in the natural resource base. An environmental quality agency and laboratory will be established. The key foci will be on forest ecosystems and climate change, in reaction to the research findings reflected in the Report, which indicate these as key factors in terms of poverty reduction and the economic development of the country.

At a broader level, donors, international research institutions and NGOs have invested large resources in research which will either feed into their own specific programmes or into government decision making. These are too many to list, but some examples include the following:

- the Planet Reviewed Expedition (see Box 4);

- the University of Edinburgh research into carbon sequestration by miombo tree species, as part of the Envirotrade carbon trading and tree planting programme in the buffer area of Gorongosa National Park;

- The Bioversity International Programme in Niassa Reserve relating to the use of trees and how this could be more effectively managed;

- the WWF Eastern Africa Coastal Forest Ecoregion Programme, which is supporting research into the remaining coastal forests in Mozambique, both in terms of their biodiversity and their use for sustainable livelihoods; and

- the research and modelling for the INGC report on climate change and potential scenarios and impacts prepared by INGC and UEM ${ }^{79}$ and funded by Denmark, UNDP and GTZ, on which key strategies are now being proposed for climate change programmes, including forest replanting, wildfire control, etc.

These studies are playing a valuable contribution to the understanding of forest ecosystem services and their inter-action with human well-being. However, there is often difficulty with translating this knowledge into action which would increase human resilience and community well-being, and reduce poverty. 
It is indicative of the lack of knowledge about forests that the Planet Reviewed Expedition found 36 new species and 68 newly recorded species in Mozambique. In addition, 7000 hectares of virgin rainforest were discovered on Mt Mabu when in 2009 a search using Google Earth revealed the area. This area has high biodiversity because the forest is largely untouched due to its isolation and protection by local communities who used the forest as a refuge during the civil war. Five new butterfly species and a new variety of adder were found during the initial expedition. ${ }^{80}$

\section{The economics of forest ecosystems}

\subsection{Genuine valuation of services provided by forests}

Despite the social, environmental and economic value of biodiversity and ecosystem services, there is currently a lack of knowledge, tools and techniques to estimate their "true" value. By not quantifying in monetary terms the contributions of the ecosystem services provided by the forests, Mozambique is seriously undervaluing their importance.

If, for example, the value of each forest ecosystem service (such as its being a source of water and air, a carbon store, the ground of biodiversity, a producer of soil nutrients, a mitigator of erosion and flooding) were considered in the fiscal account of the nation, there would be greater responsibility in the way this resource was used and enjoyed.

Two examples serve to illustrate the impact that this kind of accounting could have on current thinking:

- According to the Stockholm International Water Institute, the total economic value of mangrove forests globally stands at USD 6,075 per ha per year. Assuming that the same average can be used for Mozambique, even a $0.1 \%$

Bird Life International 2009 www.sciencedaily.com. 
annual reduction in mangrove areas may cost the national economy some USD 2 million. ${ }^{81}$

- An analysis of the socio economic aspects of coastal forests of Mozambique confirms that the livelihoods of coastal populations are supported by resources such as timber, construction materials, fruits, tubers, meat, honey, and medicinal plants. The authors estimate that the value of the use of medicinal plants alone from coastal forests may reach USD 80 million per year. ${ }^{82}$

\subsection{PES \& REDD+}

Payment for ecosystem services (PES) is increasingly popular in developing countries as a means of supporting conservation and the sustainable management of forest ecosystems. The benefits are seen as the ability of PES to support environmental conservation while allowing for economic development or for the support of local communities, as well as the understanding that if ecosystem services do not have an economic value and are not accounted for they are unlikely to be sustainably managed. PES can also provide a framework for trade-offs between use and management, while supporting livelihoods. ${ }^{83}$ These payments are linked to carbon sequestration as part of climate change and adaptation programmes; to water quality retention through forest catchment management; to biodiversity management and protection through forest conservation and management; and to clean development mechanisms relating to energy use which limits the use of forest products.

There are already a number of carbon sequestration projects in Mozambique operated by NGOs or private companies, including:

- the planting of 54000 ha of exotic forests in Lurio (Nampula Province) by the Green Resources, a Norwegian Company, and of 54 000ha in the Sanga District (Niassa Province) by the Malonda Tree Company. The benefits of these two

Assuming the total area to be 396,080 ha - as per the 1990 inventory.

Albano 2004 coastalforests.tfcg.org.

Corbera, Gonzalez Sobernis and Brown 2009 Ecological Economics. 
projects are that trees will be grown for construction material and firewood. There are major concerns, though, that the exotic plantations will deplete groundwater sources and that their establishment as monocultures will result in large losses of biodiversity in these areas.

- The Carbon Livelihoods Projects run by the UK company Envirotrade, which is operating in the Quirimbas National Park, in the Nhampakue and Inhamitanga Forest Reserves and in the buffer of the Gorongosa National Park in Nhambita community. The objective is to create alternative livelihoods in order to reduce the pressure on natural resources in the reserves and national parks, and to reduce forest clearance for agriculture and energy requirements, through the planting of nitrogen fixers such as fruit trees, and to improve agricultural practices. All activities are supported by academic researchers from the University of Edinburgh, and the application of their studies, such as the carbon sequestration ability of indigenous miombo and mopane trees.

Such projects are relatively small-scale, however. Internationally, Mozambique has been selected as one of the countries for the implementation of a REDD+ programme that was initially proposed at UNFCCC-COP 11, which was held in Montreal in 2005. The process of developing workable mechanisms has been complex at an international as well as a national level. In 2008 Mozambique prepared and submitted a Readiness Plan Idea Note (RPN) to the World Bank's Forest Carbon Partnership Facility (FCPF). In 2009 a National REDD+ Working Group was set up with the aim of developing a REDD+ strategy which would be used as a basis for pilot projects, as well as of preparing the Readiness Preparation Proposal (R-PP). In addition in 2009 MICOA and the Sustainable Amazon Foundation (Fundação Amazonas Sustentável FAS) in

Box 5 - Governance aspects which deter effective PES implementation (Bond et al, 2009)

Lenient enforcement of existing forest laws and regulations

Incompatibilities between land-use and forest laws

Forest rules that favour large-scale commercial developments over local interests

Corruption and patronage that facilitate illegal activities (e.g. illegal logging) Unclear or overridden local rights of ownership and access to resources

Onerous or absent procedures for communities to secure rights

Weak institutional accountability

Brazil signed a memorandum of understanding 
as part of the South-South cooperation on REDD+, which aims to promote zero deforestation and develop a working relationship through cross-experience exchanges in terms of implementation, the development of PES mechanisms, the design of a consultation process for the REDD+ strategy, and the sharing of technical experience in monitoring, reporting and verification. ${ }^{84}$ This process was integral to the release of the draft REDD+ strategy in 2010.

MICOA and DNTF, under MINAG, are leading the process. MICOA is coordinating the process but MINAG will be responsible for the implementation, with research support from Eduardo Mondlane University. There is recognition in the draft REDD+ strategy that the main causes of deforestation are not controlled by the forestry sector but by other ministries, such as energy and mining. There is a clear recognition that intersectoral coordination will be critical to the success of reducing deforestation.

The REDD+ strategy also calls for a pro-poor implementation methodology, recognising the high dependency of Mozambicans on forestry resources. The draft strategy therefore proposes a payment for ecosystem services (PES) approach, which will target local communities involved in subsistence agriculture. ${ }^{85}$

The initial consultations were conducted in 2010 at national, provincial and district level in Niassa, Nampula, Zambézia, Tete, Gaza and Maputo, as well as at community level in Tete. In 2011 the focus of the consultations was on the district and private sectors, and also involved a national campaign to raise awareness of REDD+ itself.

According to Wertz-Kanounnikoff, Sitoe and Salamao, ${ }^{86}$ the REDD+ process in Mozambique has largely been driven by Mozambicans and not consultants, as the draft REDD+ strategy was written before FCPF support of the R-PP development

\footnotetext{
84 The South-South initiative was provided with technical and financial support by the Norwegian Embassy in Maputo, as it was realised that Mozambique had very limited experience in PES implementation, especially at Government level.

85 Wertz-Kanounnikoff, Sitoe and Salamao How is REDD+ Unfolding; Nhantumbo and Izindine Preparing for REDD.

86 Wertz-Kanounnikoff, Sitoe and Salamao How is REDD+ Unfolding.
} 
was requested, and it has therefore been more inclusive than in other countries. In addition the South-South initiative has played a significant role in the thinking informing the strategic approach of REDD+.

However, there are still many challenges. The first is to develop ways in which the REDD+ process can target the sectors which are the drivers of deforestation, and to decide what activities should be prioritised. To date inter-sectoral coordination has been weakly implemented and other sector ministries do not regard the implementation of REDD+ as a high priority. ${ }^{87}$

Secondly, there is a concern that REDD+ funding will be used to finance exotic tree planting and biofuel projects which will have adverse impacts on indigenous forests, biodiversity, and water regulating systems. If this were to occur, it could result in increased conflict over land and natural resources. ${ }^{88}$

Thirdly, while the legislative framework exists which affords substantial use and ownership rights to communities with regards to forestry, and allows communities to participate in sustainable forestry management, there has been limited implementation on the ground of the benefit sharing. This is so, although more than 70 community-based natural resource management (CBNRMs) initiatives have been established since the 1990s. ${ }^{89}$ Limitations include the communities' lack of the capacity to access and use the rights which are legally theirs, including the $20 \%$ royalties from timber concessions. Lessons need to be learnt from these experiences to ensure that the payments for REDD+ based activities reach the communities and are used to enhance livelihoods. The ability to negotiate trade-offs between stakeholders will also be key to the process.

The fourth challenge is the lack of real information and research on carbon sequestration and the effective functioning of PES in general in a Mozambican

\footnotetext{
Wertz-Kanounnikoff, Sitoe and Salamao How is REDD+ Unfolding. Justiça Ambiental REDD in Mozambique.

Wertz-Kanounnikoff, Sitoe and Salamao How is REDD+ Unfolding; Nhantumbo and Izindine Preparing for REDD.
} 
environment. The monitoring of the effectiveness of implementation will be a large challenge as well, in terms of developing access to data at a reasonable cost, due to the lack of technical capacity in the country and the need for transparent data analysis and management. ${ }^{90}$ There are concerns that REDD+ will be used fraudulently and that forest systems will not be managed or protected, as communities will not have received the financial benefits promised in the process. As stated by Peter Younger, Interpol environment crimes specialist, in October 2009: ${ }^{91}$

\begin{abstract}
Alarm bells are ringing. It is simply too big to monitor. The potential for criminality is vast and has not been taken into account by the people who set it up... Organised crime syndicates are eyeing the nascent forest carbon market. ... Fraud could include claiming credits for forests that do not exist or were not protected or by land grabs. It starts with bribery or intimidation of officials, then there's threats and violence against those people. There's forged documents too. Carbon trading transcends borders. I do not see any input from any law enforcement agency in planning REDD.
\end{abstract}

Due to the governance complexities described in the previous section, as well as those listed in Box 5, there are grave concerns in Mozambique regarding whether or not PES and REDD+ will be effective in a Mozambican context.

Finally, and linked to the present lack of monitoring and systems of accountability, there is a real challenge in terms of leveraging financing for REDD+ initiatives. The lack of the capacity to monitoring activities will be a huge limitation. However, without this capacity, long-term financial investment by donors will be difficult to come by. This difficulty has been exacerbated by the world economic crisis, where donors are increasingly cautious in terms of their financial investments and need to see clear and tangible results and benefits for the money invested.

\title{
5.3 Other economic instruments
}

Little has so far been done to examine the potential for other economic instruments in influencing behaviour with respect to the services provided by forests. We have

\footnotetext{
90 Bond et al Incentives to Sustain Forest Ecosystem Services.

91 Vidal 2009 http://www.guardian.co.uk/environment/2009/oct/05/un-forest-protection.
} 
noted already that the key mechanism for channelling revenue back to local community groups, the payment of the $20 \%$ of stumpage fees, has been slow in implementation and remains hampered by overly bureaucratic procedures. In addition, there are no mechanisms, for example, for systematically updating the forest timber royalties based on the market prices of the products or the fluctuation of the exchange rate. This means that not only the government loses revenue, but that communities lose out too. The government's policy and mechanisms for encouraging the competitive processing of higher added-value wood products have also been weak and undermined by the pressure to export logs by both simple licensees and concessionaires. The system of fines and particularly the mechanism for the collection of the money and payment to the local authorities is weak.

\section{Conclusion}

Laws and legal recognition can achieve only so much. The legal framework for the protection and management of forest ecosystem services in Mozambique is comprehensive and fully protects the rights of the communities which depend on the forests for their livelihoods. However, governance is relatively weak with respect to the existing institutions and regulations at local and national levels which are meant to mediate access to and the use of these ecosystem services. The high reliance on forest resources for the livelihoods of over $80 \%$ of the population means that the government resolve to enforce the legislation is often weakened, as there are limited alternative sources of income generation in the rural areas.

It is clear that the present trend of deforestation is not sustainable in terms of maintaining the forest ecosystem and services it provides. Given the lack of strong governance systems, the capacity to enforce the existing legislation, and a strategic perspective on the use, management and conservation of the country's forests, the pressures on them are likely to increase. The SEAs, territorial planning and REDD+ are still in their infancy, and one must hope that they will prove stronger than indicated in this paper and, with the right political and donor backing, and supported by applied research and monitoring, will provide clear direction to the necessary 
interventions. In addition, capacity will need to be developed at all levels of society and government, with a focus on the rights of communities to have access to forest resources. Systems of adaptive co-management should be promoted wherever possible. 
Annexure 1 - Summary of the state of the ecosystem services in Mozambique and the human induced drivers of change

\begin{tabular}{|c|c|}
\hline $\begin{array}{l}\text { State of ecosystem } \\
\text { services in } \\
\text { Mozambique }\end{array}$ & Human induced drivers of change \\
\hline $\begin{array}{l}\text { Rapid declines in } \\
\text { biodiversity (with } \\
\text { MICOA (2008) predicting } \\
\text { up to } 80 \% \text { losses by } 2025 \\
\text { around high density } \\
\text { areas, transport corridors } \\
\text { and coastal zone) }\end{array}$ & $\begin{array}{l}\text { Rapid deforestation and habitat fragmentation from } \\
\text { wood extraction and logging, conversion of areas to agriculture, } \\
\text { Slash and burn agriculture, and hunting with fire } \\
\text { resulting in damage or destruction to forests } \\
\text { Over-exploitation of fuel resources for charcoal and } \\
\text { firewood, especially surrounding urban areas and along main } \\
\text { transport corridors } \\
\text { Exploitation of mineral resources, resulting in forest } \\
\text { clearance } \\
\text { Illegal hunting }\end{array}$ \\
\hline $\begin{array}{l}\text { Food and Fibre } \\
\text { provision (with } \\
\text { increasing child } \\
\text { malnutrition and }\end{array}$ & $\begin{array}{l}\text { Low agricultural productivity } \\
\text { Soil degradation, reducing production } \\
\text { Rainfall variability, causing both droughts and floods } \\
\text { Livestock diseases, diminishing herds } \\
\text { Plant diseases (e.g.cassava brown-streaking disease, coconut } \\
\text { yellow wilting disease, cashew (oidio), impacting on food } \\
\text { production, food security and income generating opportunities. }\end{array}$ \\
\hline $\begin{array}{l}\text { Water supply, } \\
\text { purification and } \\
\text { regulation (with } \\
\text { increasing floods and at } \\
\text { same time surface waters } \\
\text { drying up for longer } \\
\text { periods. INGC (2009) } \\
\text { predicts major water } \\
\text { scarcity across } \\
\text { Mozambique starting in } \\
2025 \text { ) }\end{array}$ & $\begin{array}{l}\text { Deforestation (as above), causing changes in water flows and } \\
\text { sedimentation. } \\
\text { Industrial development, causing pollution from chemical } \\
\text { discharges } \\
\text { Mining development resulting in forestry clearance, increased } \\
\text { sedimentation, changes in water levels } \\
\text { Lack of sanitary facilities causing soil, surface and ground } \\
\text { water contamination } \\
\text { Clearance of wetlands for urbanisation and agriculture, } \\
\text { causing water quality declines and increased flooding } \\
\text { downstream } \\
\text { Over-extraction of water upstream mainly in neighbouring } \\
\text { countries, causing reduction of flows in Mozambique }\end{array}$ \\
\hline $\begin{array}{l}\text { Fuel provision (Sitoe } \\
\text { (2007) has indicated an } \\
\text { average consumption of } \\
\text { woodfuel of } 2 \mathrm{~m}^{3} / \text { person/ } \\
\text { year. This is greater than } \\
\text { the annual regeneration } \\
\text { rates of miombo } \\
\text { woodlands per hectare. }\end{array}$ & $\begin{array}{l}\text { Slash and burn agriculture, and hunting with fire } \\
\text { resulting in damage or destruction to forests } \\
\text { Deforestation for commercial agriculture, commercial } \\
\text { forestry and urbanisation } \\
\text { Over-exploitation of fuel resources for charcoal and } \\
\text { firewood, especially surrounding urban areas and along main } \\
\text { transport corridors }\end{array}$ \\
\hline
\end{tabular}




\begin{tabular}{|l|l|}
\hline $\begin{array}{l}\text { State of ecosystem } \\
\text { services in } \\
\text { Mozambique }\end{array}$ & Human induced drivers of change \\
\hline & $\begin{array}{l}\text { Logging both legal and illegal diminishing biodiversity of } \\
\text { species }\end{array}$ \\
\hline
\end{tabular}




\section{Bibliography}

Arampatzis, Manos and Manou "Governance and Ecosystem Management"

Arampatzis S, Manos B and Manou D "Governance and Ecosystems Management for Conservation of Biodiversity" in Proceedings of the 4th International Conference on Citizens and Governance for Sustainable Development (CIGSUD), Vilnius Lithuania, September, 2006

Bond et al Incentives to Sustain Forest Ecosystem Services

Bond I et al Incentives to Sustain Forest Ecosystem Services: A Review and Lessons Learnt for REDD (International Institute for Environment and Development London 2009)

Brunkhorst 2004 ESEP

Brunkhorst DJ "Turning Points Towards Sustainability: Integrative Science and Policy for Novel (but Real) Landscape Futures" 2004 Ethics in Science and Environmental Politics 83-91

Cabral and Francisco Environmental Institutions

Cabral L and Francisco D Environmental Institutions, Public Expenditure and the Role for Development Partners: Mozambique Case Study (ODI London 2008)

Corbera, Gonzalez Sobernis and Brown 2009 Ecological Economics

Corbera E, Gonzalez Sobernis C and Brown K "Institutional Dimensions of Payment for Ecological Services: An Analysis of Mexico's Carbon Forestry Programme" 2009 Ecological Economics 743-761

Council of Ministers MOTIS

Council of Ministers Mozambique Science, Technology and Innovation Strategy (MOTIS) (The Council Maputo 2006) 
DEAT Strategic Environmental Assessments

Department of Environmental Affairs and Tourism Strategic Environmental Assessments, Integrated Environmental Management: Information Sheet 10 (DEAT Pretoria 2004)

DNTF Relatorio Annual do Sector de Terras e Florestas

Direcção Nacional de Terras e Florestas Relatorio Annual do Sector de Terras e Florestas (GoM Maputo 2008)

DNTF Relatório Annual da Direcção de Florestas e Fauna Bravia

Direcção Nacional de Terras e Florestas Relatório Annual da Direcção de Florestas e Fauna Bravia - 2007(GoM Maputo 2008)

Hanlon Poverty Decreasing in Mozambique?

Hanlon J Is Poverty Decreasing in Mozambique? Paper Presented to the Inaugural Conference of the Instituto de Estudos Sociais e Economicos, 19 September 2007(IESE Maputo 2007)

Huitric Biodiversity, Ecosystem Services and Resilience

Huitric M (ed) Biodiversity, Ecosystem Services and Resilience Governance for a Future with Global Changes (Stockholm University Stockholm 2009)

Johnstone, Cau and Norfolk Forestry Legislation

Johnstone R, Cau B and Norfolk S Forestry Legislation in Mozambique: Compliance and the Impact on Forest Communities (IIED London 2004)

Justiça Ambiental REDD in Mozambique

Justiça Ambiental REDD in Mozambique: An Independent Monitoring Report (Justica Ambiental Maputo 2010) 
Katere, Minag and Vanhanen (eds) Making Sub-Saharan African Forests Work Katere Y, Minag P and Vanhanen H (eds) Making Sub-Saharan African Forests Work for People and Nature: Policy Approaches in a Changing Global Environment (WFSE/ICRAF/CIFOR/METLA Nairobi 2009)

Mackenzie, Smith and Fairfield, 2005 Insight

Mackenzie RKT, Smith RS and Fairfield CA "New Directions for NDT in Forestry" 2005 Insight 47(7):416-420.

MacQueen Power to the Poor

MacQueen D Power to the Poor: Sustainable Energy at the Base of the Pyramid(IIED London 2009)

Malleux Avaliação dos Recursos Florestais

Malleux J Avaliação dos Recursos Florestais da República Popular de Moçambique (GoM/FAO Maputo 1980)

Marzolli Avaliacao Integrada das Florestas

Marzolli A Avaliacao Integrada das Florestas de Mocambique. Inventario Florestal Nacional (DNTF Maputo 2007)

MICOA Evaluation of the Interaction between Biodiversity and Poverty Ministério para a Coordenação da Acção Ambiental Report on the Study of the Evaluation of the Interaction between Biodiversity and Poverty in Mozambique (GoM Maputo 2008)

MICOA State of the Environment

Ministério para a Coordenação da Acção Ambiental State of the Environment Report: First Report (GoM Maputo 2011) 
Millennium Ecosystem Assessment Ecosystems and Human Well-being

Millennium Ecosystem Assessment Ecosystems and Human Well-being: Synthesis (Island Press Washington DC 2005)

Ministerio da Industria e Comercio Estrategia para o Desenvolvimento

Ministerio da Industria e Comercio Estrategia para o Desenvolvimento das Micro, Pequenas e Medias Empresas em Mocambique (GoM Maputo 2005)

Mourana and Serra 20 Passos para Sustentabilidade Florestal

Mourana B and Serra C 20 Passos para Sustentabilidade Florestal em Moçambique (CIP/Amigos da Floresta Maputo 2011)

Müller, Sitoe and Mabunda Assessment of the Forest Reserve Network

Müller T, Sitoe A and Mabunda R Assessment of the Forest Reserve Network in Mozambique (WWF Mozambique Maputo 2005)

Nhancale et al Small and Medium Forest Enterprises

Nhancale B et al Small and Medium Forest Enterprises in Mozambique - IIED Small and Medium Forest Enterprises Series No 25 (Centro Terra Viva and IIED London 2009)

Nhantumbo and Izindine Preparing for REDD

Nhantumbo I and Izindine S Preparing for REDD in Dryland Forests: Investigating the Options and Potential Synergy for REDD Payments in Miombo Eco-region (Mozambique Country Study) (IIED Edinburgh 2009)

Nhantumbo and Salomão Biofuels, Land Access and Rural Livelihoods Nhantumbo I and Salomão A Biofuels, Land Access and Rural Livelihoods in Mozambique (IIED London 2010) 
Pedersen On the Road to the Knowledge Economy

Pedersen LF On the Road to the Knowledge Economy. An Analysis of the Case of Mozambique in the Introduction of Knowledge and Skills as a Foundation for Economic Growth (Master's Thesis Aalborg University 2008)

Rechkemmer and Von Falkenhayn 2009 European Physical Journal Conferences

Rechkemmer A and Von Falkenhayn L "The Human Dimension of Global Environmental Change: Ecosystem Services, Resilience and Governance" 2009 European Physical Journal Conferences 1, 3-17

Saket Updating of the Exploratory National Forest Inventory

Saket M Report on the Updating of the Exploratory National Forest Inventory (FAO Rome 1994)

Shackelton et al Links Between Ecosystems and Poverty Alleviation

Shackelton C et al Links Between Ecosystems and Poverty Alleviation: Situational Analysis for Arid and Semi-arid Lands in Southern Africa (Consortium on Ecosystems and Poverty in Sub-Saharan Africa London 2008)

Sitoe Avaliacao dos Niveis de Consume de Energia

Sitoe A Avaliacao dos Niveis de Consume de Energia de Biomass nas Provincias de Tete, Nampula, Zambezia, Sofala, Gaza e Maputo (GoM Maputo 2007)

UN World Statistics Pocketbook

United Nations World Statistics Pocketbook: Country Profile Mozambique (UN New York 2010)

Van Logchem and Brito (eds) Synthesis Report

Van Logchem B and Brito R (eds) Synthesis Report: Study on the Impact of Climate Change on Disaster Risk in Mozambique: Climate Change Report (INGC Maputo 2009) 
Wertz-Kanounnikoff, Sitoe and Salamao How is REDD+ Unfolding

Wertz-Kanounnikoff $S$, Sitoe A and Salamao A How is REDD+ Unfolding in Southern Africa's Dry Forests? A Snapshot from Mozambique: Info Brief No 37 (CIFOR Bogor 2011)

Wilson et al Innovating for Environment and Society

Wilson E et al (2009) Innovating for Environment and Society: An Overview (London IIED 2009)

Wong, Roy and Duraiappah Connecting Poverty and Ecosystem Services

Wong C, Roy M and Duraiappah A Connecting Poverty and Ecosystem Services. A series of Seven Country Scoping Studies: Focus on Mozambique (UNEP Nairobi 2005)

WRI Millenium Ecosystem Assessment Synthesis Report

World Resource Institute The Millenium Ecosystem Assessment Synthesis Report (WRI Washington DC 2005)

\section{Register of legislation}

Constitution of Mozambique, 1990

Environmental Framework Law 20/97

Environmental Impact Assessment Regulations (Decree 41/2008)

Forestry and Wildlife Law 10/99

Forestry and Wildlife Regulations (Decree 12/2002)

Forestry and Wildlife Policy (Resolution 8/97)

Land Law 19/97 and related Regulations (Decree 66/98 and Ministerial Diploma 29A/2000)

Law and Regulation on Environmental Impact Assessment (Decree 45/2004)

Law $4 / 90$ of $26^{\text {th }}$ September

Law $7 / 98$ of $15^{\text {th }}$ June

Ministerial Diploma (93/2005) 
Ministerial Diploma: Addendum to EIA Process Regulation 45/2004 (198/2005)

\section{Register of international instruments}

Convention on Biological Diversity (1992)

SADC Protocol on Forestry (2002)

UN Convention to Combat Desertification (1995)

UN Framework Convention on Climate Change (1995)

\section{Register of internet resources}

Albano 2004 coastalforests.tfcg.org

Albano G 2004 Coastal Forests of Mozambique: Socio-economic Aspects Review coastalforests.tfcg.org/pubs/SocioEco-MZQ.pdf [date of use 1 Jun 2013]

Bird Life International 2009 www.sciencedaily.com

Bird Life International 2009 Many New Species Discovered in Hidden Mozambique Oasis with Help of Google Earth www.sciencedaily.com/releases/2009/01/090131125244.htm [date of use 15 Feb 2012]

Bussotti 2010 pambazuka.org

Bussotti L 2010 Rejuventating the Mozambican Knowledge Factory pambazuka.org/en/category/features/68561 [date of use 1 Jun 2013]

Cash et a/ 2006 www.ecologyandsociety.org

Cash DW et al "Scale and Cross-scale Dynamics: Governance and Information in a Multi-level World" 2006 Ecology and Society 11(2):8 www.ecologyandsociety.org/vol11/iss2/art8/ [date of use 29 May 2013] 
Consortium AGRIFOR Consult 2006 ec.europa.eu

Consortium AGRIFOR Consult 2006 Country Environmental Profile for Mozambique: Draft Final Report ec.europa.eu/development/icenter/ repository/CEP_Mozambique_200607.pdf [date of use 1 Jun 2013]

Environmental Investigation Agency First Class Connections: Log Smuggling, Illegal Logging and Corruption in Mozambique

Environmental Investigation Agency First Class Connections: Log Smuggling, Illegal Logging and Corruption in Mozambique (DFID 2013) http://illegallogging.info/item_single.php?it_id=1422\&it=document [date of use 14 June 2013]

FAO 2005 www.fao.org

Food and Agriculture Organisation of the United Nations: Rural Development Division 2005 An approach to rural development: Participatory and Negotiated Territorial Development www.fao.org/sd/dim_pe2/docs/pe2_050402d1 _en.pdf [date of use 2 Jun 2013]

McNeely 2010 irgc.org

McNeely JA 2010 People, Ecosystems and Climate: Governance Risks from Degradation of Ecosystem Services in the Face of Ongoing Climate Change irgc.org/wp-

content/uploads/2012/04/ER_and_Ecosystem_Services_McNeely.pdf [date of use 29 May 2013]

Norfolk S and Cosijn M

Norfolk $S$ and Cosijn $M$ "Development and the balancing of interests in Mozambique" in Faure $M$ and Du Plessis W Balancing of Interests in Environmental Law in Africa (PULP Pretoria 2011) 295-340 
Resilience Alliance 2010 www.redagres.org

Resilience Alliance 2010 Assessing Resilience in Social-ecological Systems:

Workbook for Practitioners. Version 2.0 www.redagres.org/Assessing \%20Resilience\%20in\%20Social-Ecological\%20Systems.pdf [date of use 1 Jun 2013]

Smith and Stirling 2010 Ecology and Society

Smith A and Stirling A "The Politics of Social-ecological Resilience and Sustainable Socio-technical Transitions" 2010 Ecology and Society 15(1):11www.ecologyandsociety.org/vol15/iss1/art11/ [date of use 15 Feb 2012]

Van der Plas 1995 www.worldbank.org

Van der Plas R 1995 Burning Charcoal Issues: Energy Note No 1 www.worldbank.org/html/fdp/enrgy/energynotes/energy01.html [date of use 15 Feb 2012]

Vidal 2009 http://www.guardian.co.uk/environment/2009/oct/05/un-forest protection

Vidal J "UN's forest protection scheme at risk from organised crime, experts warn" The Guardian http://www.guardian.co.uk/environment/2009/oct/05/ un-forest-protection [date of use 14 June 2013]

\section{List of abbreviatons}

CBD Convention on Biological Diversity

CBNRMs Community-based natural resources management

CDM Clean Development Mechanism

CIFOR Centre for International Forestry Research

CONDES National Council for Sustainable Development (Mozambique)(Conselho Nacional do Desenvolvimento Sustentável)

COGEP Local Participatory Management Councils (Conselhos Locais de Gestão Participativa) 
CONDES National Council for Sustainable Development

CPI Investment Promotion Centre (Centro para Promoção de Investimento)

CRIC Committee for the Review of the Implementation of the Convention (UN Convention to Combat Desertification)

DEAT Department of Environmental Affairs and Tourism

DNTF National Directorate of Forests and Land (Direcção Nacional de Terras e Florestas)

DUT Dresden University of Technology

EAS Simplified environmental assessment (Estudo Ambiental Simplificado)

EIA Environmental impact assessment (Estudo de Impacto Ambiental)

EMP Environmental management plan

ESEP Ethics in Science and Environmental Politics

FAO Food and Agriculture Organisation of the United Nations

FAS Sustainable Amazon Foundation(Fundação Amazonas Sustentavel)

FCPF Forest Carbon Partnership Facility

FMP Forest management plan

GDP Gross domestic product

GMO genetically modified organisms

GTZ German Agency for Technical Cooperation (Deutsche Gesellschaft für Technische Zusammenarbeit)

ICARRD International Conference on Agrarian Reform and Rural Development

IIAM Institute of Agrarian Investigation (Instituto de Investigação Agrária de Moçambique)

INGC National Institute for the Management of Disasters (Instituto Nacional de Gestão das Calamidades)

MA Millennium Ecosystem Assessment

MAE Ministry of State Administration (Ministério de Administração Estatal)

MCLT Mozambican Carbon Livelihoods Trust

MICOA Ministry for the Co-ordination of Environmental Affairs (Ministério para a Coordenação da Acção Ambiental)

MINAG Ministry of Agriculture (formerly MADER - until 2004) (Ministérioda Agricultural)

MITUR Ministry of Tourism (Ministériodo Turismo)

MOTIS Mozambique Science, Technology and Innovation Strategy 
MPD Ministry of Planning and Development (Ministériopara Planificação e Desenvolvimento)

NAPA National Adaptation Programme of Action

NBSAP National Biodiversity Strategy and Action Plan

NCB National Coordinating Body (UN Convention to Combat Desertification)

NGO Non-governmental organisation

NRM Natural resource management

NTFP Non-timber forest product

PES Payment for ecological services

PNTD Participatory and Negotiated Territorial Development

REDD Reducing Emissions from Deforestation and Forest Degradation in Developing Countries

REDD+ Goes beyond deforestation and forest degradation and includes conservation, sustainable management of forests, and the enhancement of forest carbon stocks

R-PP Readiness Preparation Proposal

R-PIN Readiness Plan Idea Note

SAREC Swedish Agency for Research Cooperation with Developing Countries

SEA Strategic environmental assessment

SFM Sustainable forest management

SIDA Swedish International Development Cooperation Agency

SLH Simple licence holders

SME Small and medium enterprises

SPFFB Provincial Forest and Wildlife Services

UEM Eduardo Mondlane University (Universidade deEduardo Mondlane)

UN United Nations

UNCCD UN Convention to Combat Desertification

UNDP United Nations Development Programme

UNEP United Nations Environment Programme

UNFCCC United Nations Framework Convention on Climate Change

UNU- $\quad$ Integrated Management of Material Fluxes and of Resources

FLORES

WRI World Research Institute 